\title{
Economic analysis and optimization of combined solar district heating technologies and systems
}

Huang, Junpeng; Fan, Jianhua; Furbo, Simon; Chen, Daochuan; Dai, Yanjun; Kong, Weiqiang

Published in:

Energy

Link to article, DOI:

10.1016/j.energy.2019.115886

Publication date:

2019

Document Version

Peer reviewed version

Link back to DTU Orbit

Citation (APA):

Huang, J., Fan, J., Furbo, S., Chen, D., Dai, Y., \& Kong, W. (2019). Economic analysis and optimization of combined solar district heating technologies and systems. Energy, 186, [115886].

https://doi.org/10.1016/j.energy.2019.115886

\section{General rights}

Copyright and moral rights for the publications made accessible in the public portal are retained by the authors and/or other copyright owners and it is a condition of accessing publications that users recognise and abide by the legal requirements associated with these rights.

- Users may download and print one copy of any publication from the public portal for the purpose of private study or research.

- You may not further distribute the material or use it for any profit-making activity or commercial gain

- You may freely distribute the URL identifying the publication in the public portal 


\section{Economic analysis and optimization of combined solar district heating technologies and systems \\ Junpeng Huang ${ }^{1}$, Jianhua Fan ${ }^{1 *}$, Simon Furbo ${ }^{1}$, Daochuan Chen², Yanjun Dai ${ }^{2}$, Weiqiang Kong ${ }^{1}$ \\ 1, Department of Civil Engineering, Technical University of Denmark, Copenhagen (Denmark) \\ 2, School of Mechanical and Energy, Shanghai Jiaotong University, Shanghai (China)}

Abstract: To find an optimal economic solution for solar district heating (SDH) in China, an evaluation model based on the levelized cost of heat $(\mathrm{LCOH})$ is developed. A Python program is developed to calculate the $\mathrm{LCoH}$ of SDH systems using the quasi-dynamic test method. Based on these calculations, the trend of $\mathrm{LCOH}$ with solar collector area under different heating load intensities, heating terminal units, heated areas and land rents is discussed. The optimal solar collector area and the solar fraction are determined for combinations of solar thermal with four types of auxiliary heat sources, including air source heat pumps, ground source heat pumps, gas boilers and gas boilers with seasonal heat storage. The calculations show an economic optimal solar fraction of $11 \%-33 \%$ for a SDH system with heat pumps. High dependency of $\mathrm{LCOH}$ on network temperature is found for a SDH system with gas boilers. Seasonal heat storage minimizes $\mathrm{LCOH}$ of a SDH system with gas boilers at 100\% solar fraction. The findings can be used as a reference for local authorities, consultants and engineers in the early energy planning to determine the optimal proportion of solar energy in a district heating system with the lowest operating cost.

Keywords: economic analysis, solar district heating, levelized cost of heat, heat pump, optimization

\section{Nomenclature}

\begin{tabular}{|ll|}
\hline Abbreviations \\
ASHP & air source heat pump \\
BAU & business as usual \\
EH & electric heating \\
FPC & flat plate collector \\
GB & gas boiler \\
GSHP & ground source heat pump \\
HAS & heated area scenarios \\
HLS & heating load scenarios \\
HTS & heating terminal units scenarios \\
LRS & land rent scenarios \\
LCOH & levelized cost of heat \\
SDH & solar district heating \\
SF & solar fraction \\
SHS & seasonal heat storage \\
ST & solar thermal \\
\hline
\end{tabular}

\section{Symbols}

$I_{0} \quad$ initial investment, $\mathrm{CNY}$

$I_{s c} \quad$ cost of solar collectors, $\mathrm{CNY}$

* Corresponding author. ISES member Te1: +45-42251889 Fax: +45-45883282

Email address: jif@byg.dtu. dk (Jianhua Fan) 


\begin{tabular}{|c|c|}
\hline$H_{l}$ & heat loss rate of the heating pipe network, $\%$ \\
\hline$S_{0}$ & subsidies and incentives, CNY \\
\hline$C_{t}$ & operation and maintenance costs, $\mathrm{CNY}$ \\
\hline$E_{t}$ & saved final energy (in year $\mathrm{t}$ ), kWh \\
\hline$T R$ & tax rate, $\%$ \\
\hline$D E P_{t}$ & asset depreciation (year t), CNY \\
\hline$R V$ & residual value of system, CNY \\
\hline$r$ & discount rate, $\%$ \\
\hline$T$ & period of analysis, year \\
\hline$p_{\text {land }}$ & annual land rent, CNY/year \\
\hline$S$ & gross solar collector area, $\mathrm{m}^{2}$ \\
\hline$Q_{t}$ & total heat demand of the benchmark load model in year $\mathrm{t}, \mathrm{kWh}$ \\
\hline$q_{t}$ & instantaneous heat production per $\mathrm{m}^{2}$ of solar collectors, $\mathrm{W} / \mathrm{m}^{2}$ \\
\hline$\tau$ & time step, 1 hour \\
\hline$G$ & total solar radiation in the collector plane, $\mathrm{W} / \mathrm{m}^{2}$. \\
\hline$G_{b}$ & beam solar radiation in the collector plane, $\mathrm{W} / \mathrm{m}^{2}$ \\
\hline$G_{d}$ & diffuse solar radiation in the collector plane, $\mathrm{W} / \mathrm{m}^{2}$ \\
\hline$\eta$ & efficiency of a solar collector, $\%$ \\
\hline$\eta_{0}$ & peak collector efficiency, \% \\
\hline$K_{\theta, d}$ & incidence angle modifier for diffuse solar radiation,- \\
\hline$K_{\theta, b}$ & incidence angle modifier for beam solar radiation,-- \\
\hline$\theta$ & incidence angle for radiation, ${ }^{\circ}$ \\
\hline$a_{1}$ & heat loss coefficient of collector at ambient temperature, $\mathrm{W} / \mathrm{m}^{2} \mathrm{~K}$ \\
\hline$a_{2}$ & temperature dependence of heat loss coefficient of collector, $\mathrm{W} / \mathrm{m}^{2} \mathrm{~K}^{2}$ \\
\hline$t_{a}$ & ambient temperature, ${ }^{\circ} \mathrm{C}$ \\
\hline$t_{m}$ & mean solar collector fluid temperature, ${ }^{\circ} \mathrm{C}$ \\
\hline $\mathrm{COP}_{a}$ & coefficient of performance of an air source heat pump \\
\hline $\mathrm{COP}_{g}$ & coefficient of performance of a ground source heat pump \\
\hline$T_{e v a}$ & evaporation temperature, ${ }^{\circ} \mathrm{C}$ \\
\hline$T_{\text {con }}$ & condensation temperature, ${ }^{\circ} \mathrm{C}$ \\
\hline$S_{y}$ & daily average hours of sunshine during the heating period, $\mathrm{h} /$ day \\
\hline$d$ & number of heating days,-- \\
\hline$p_{e}$ & price of electricity, CNY / kWh \\
\hline$p_{\text {shs }}$ & price per $\mathrm{m}^{3}$ of heat storage, $\mathrm{CNY} / \mathrm{m}^{3}$ \\
\hline$p_{F P C}$ & price of flat plate solar collectors, $\mathrm{CNY} / \mathrm{m}^{2}$ \\
\hline$P_{\text {pump }}$ & power consumption by circulation pumps per $\mathrm{m}^{2}$ solar collector, $\mathrm{W} / \mathrm{m}^{2}$ \\
\hline$O_{s c f}$ & operating cost of a solar collector field, CNY \\
\hline$M_{s c f}$ & maintenance cost of a solar collector field, CNY \\
\hline$M_{\text {shs }}$ & maintenance cost of seasonal heat storage, $\mathrm{CNY}$ \\
\hline$Q_{W}$ & average daily heat consumption of a domestic hot water system, W \\
\hline$n$ & number of hot water use per unit,-- \\
\hline$q_{r}$ & hot water consumption, L / (person.day) \\
\hline$c_{w}$ & specific heat capacity of water, J / kg.K \\
\hline$\rho_{w}$ & density of water, $\mathrm{kg} / \mathrm{L}$ \\
\hline
\end{tabular}


$t_{c} \quad$ design cold water temperature, ${ }^{\circ} \mathrm{C}$

$t_{h} \quad$ design hot water temperature, ${ }^{\circ} \mathrm{C}$

1. Introduction

In the urban areas of northern China, the annual heat consumption is higher than 181 million tons of standard coal, corresponding to approximately $25 \%$ of the total energy consumption for the country's buildings[1]. Demand for heating in China is growing rapidly. Heat demand in the Hot Summer and Cold Winter areas such as the middle and lower reaches of the Yangtze River is also rising. Reliance on coal-based fuels has caused severe smog and air pollution in the heating season in northern China. Reducing the use of coal and increasing the proportion of clean energy is an opportunity and challenge for China's heating industry.

A single heat source (coal or gas) still dominates centralized heating systems in China's cities. The heat source is usually coal-fired cogeneration, gas-fired cogeneration or a dedicated district heating boiler[2],[3]. The cogeneration heating plants without heat storage facilities and reliable auxiliary heat source cause electricity overproduction in the winter heating season due to the policy of electricity production according to heating demands, which overlaps with the peak in wind power generation[4], resulting in tremendous energy waste. At present, China is aware of the importance of developing hybrid energy technologies while developing district energy systems. This is especially true for urban district heating systems. It is of paramount importance that, the heating industry carries out hybrid energy transformation in existing heating plants to reduce operating costs, increase the synergy between heat and power generation and to improve the operation efficiency of such heating plants.

District heating systems with multiple heat sources configuration are common in Europe, for instance, gas boilers combined with solar energy heat pumps/wood chip boilers combined with solar energy, heat pumps/waste heat from waste to energy plants combined with gas boilers[5][6][7][8]. The proportion of renewable energy in heating systems in Europe has reached 28\%[9], with Denmark leading at 48\% in Denmark[10] in 2015, wherein solar thermal accounted for 2\%[11] and is expected to reach $15 \%$ by 2025[12]. In China, the proportion of renewable energy in heating systems was only $2.8 \%$ in 2016 , and the contribution of solar heating was close to zero[3].

Increasing the application of renewable energy, solar heating and low-temperature heating have become the core concepts of the $4^{\text {th }}$ Generation district heating system[13]. Determination of a reasonable renewable energy share with the lowest operating cost of a heating system is one of the core factors considered in future energy planning and heat source selection. One of the significant barriers affecting the promotion of hybrid energy technologies is the unclear economics underpinning the use of multi-source heating systems. Therefore it is essential to develop an economic evaluation method to determine the optimal renewable energy ratio in multi-source heating systems.

For solar district heating systems, solar fraction is a core indicator for system design and long term operation. The current method for determining solar fraction per the current specifications in China[14] often leads to excessive consumption of auxiliary energy in winter and a surplus of heat supply in summer[15][16]. Usually, system design and configuration are not economically optimized. At the same time, the economic 
evaluation of solar assisted heating systems lacks a widely recognized methodology in the heating industry, hindering the development of solar district heating systems.

Commonly used indicators for evaluating the economics of the entire system include annual cost, annual operating expenses and investment payback time. However, due to the complexity of multiple heat sources systems, the initial investment tends to be high. As a result, the indicators articulated above cannot reflect the energy-saving advantages brought about by the long-term operation of the systems. In accordance with the life-cycle economics, under different climates and economic conditions, there must be an optimal utilization rate for solar energy.

IEA Task 54 proposes Levelized Cost of Heat $(\mathrm{LCOH})$ as an indicator assessing the costs of heat generated by solar heating systems [17] [18]. This indicator comprehensively considers economic considerations such as initial investment, operating and maintenance costs, subsidies, tax rates, discount rates, depreciation and labor costs. As a comprehensive economic evaluation indicator, $\mathrm{LCOH}$ is suitable to be used to compare results of different designs and technological solutions[19].

To find the economically optimal solar fraction for solar district heating in China, an evaluation model based on $\mathrm{LCoH}$ will be developed in this study. Based on the model, a Python program will be developed and used to calculate the $\mathrm{LCOH}$ of solar district heating systems with different designs by utilizing the quasi-dynamic test (QDT) method. Compared with the steady-state test method, the QDT method can give more accurate results in system simulations and in predictions of annual collector gains.

The results of this study provide a reference for local authorities, consultants and engineers in the early planning phase to make rational investment decisions when choosing economically feasible heat sources with the lowest heating cost in the long run.

\section{Method}

2.1. Systems description

To fully explore the potential of solar energy for district heating, four most feasible hybrid heating systems are investigated, including solar thermal combined with air source heat pumps (ST + ASHP), solar thermal combined with ground source heat pumps (ST + GSHP), solar thermal combined with gas boilers (ST + GB) and solar thermal combined with gas boilers and seasonal heat storage (ST + GB + SHS). The schematics of the four systems are shown in Table 1. Some combinations that are not common in China, e.g. solar thermal and biomass boilers, solar thermal and ASHP plus seasonal heat storage (ST + ASHP + SHS) will not be considered in the present study.

Table 1 The schematics of the four types of solar district heating systems

\begin{tabular}{lll}
\hline Types & System schematics & References \\
\hline
\end{tabular}




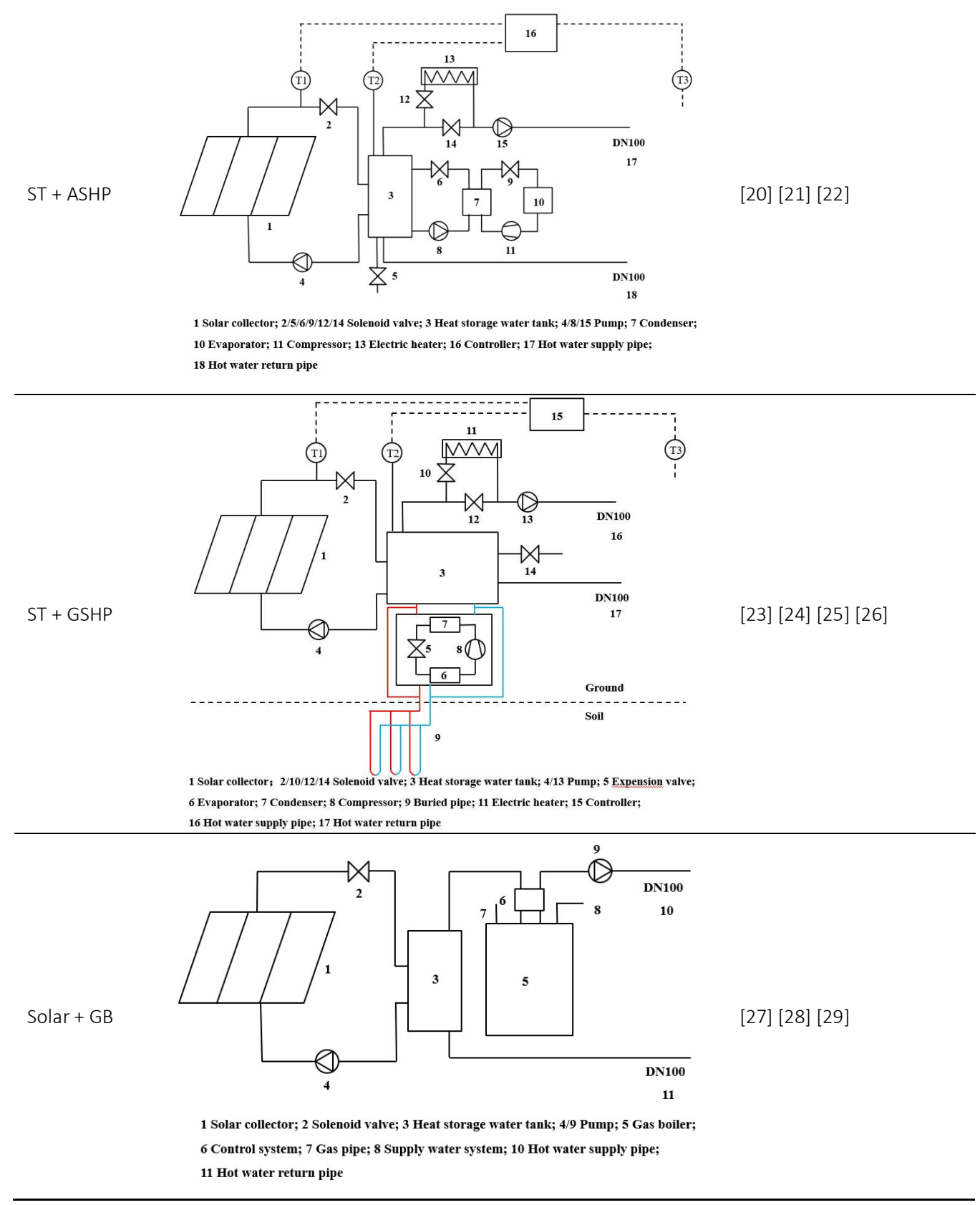




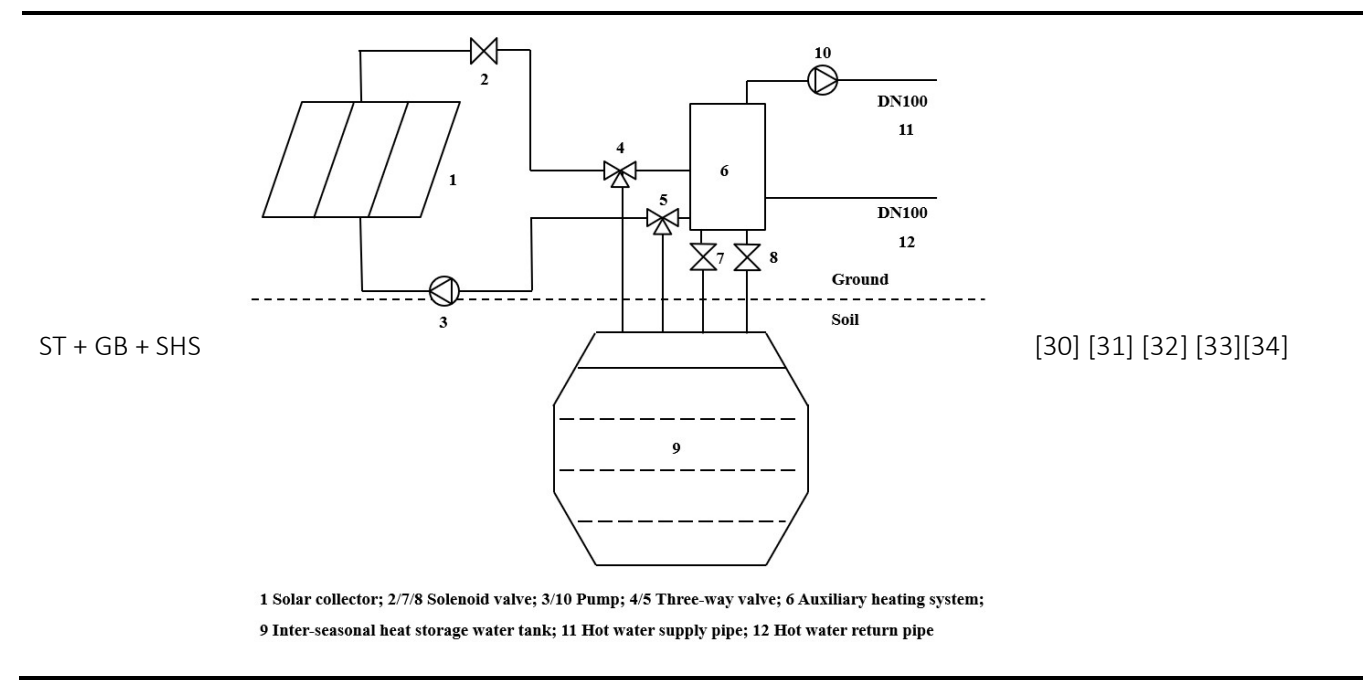

2.2. System modeling

2.2.1. The benchmark load model

Based on the current practice of solar heating[35][36], incentive policy trend[37][38] and research findings on the feasibility of solar district heating in China[39], a rural village is chosen as a reference to build a benchmark load model for a solar district heating system. According to the China National Bureau of Statistics, the housing area per capita in rural China is $45.8 \mathrm{~m}^{2}$ [40] and the residential floor space of a family of three is $137.4 \mathrm{~m}^{2}$. There are from 8 to 2000 households in a village with space heating in the northern part of China. The recent trend has been a decrease in the number of households in rural villages [41][42]. Based on these facts, a benchmark load model for district heating is built. The model village has a heated floor area of $20,000 \mathrm{~m}^{2}$ and is heated 24 hours/day in the heating season with a solar district heating system. The heating load is only for space heating, excluding the load for heating domestic hot water.

Table 2 Basic assumptions for the benchmark load model for solar district heating systems

\begin{tabular}{ll}
\hline Parameters & Value \\
\hline Heated area, $\mathrm{m}^{2}$ & 20,000 \\
\hline Number of residents & 450 \\
\hline The indoor temperature during the heating period, ${ }^{\circ} \mathrm{C}$ & 18 \\
\hline System residual value & $5 \%$ \\
\hline Length of the heat pipe network, $\mathrm{km}$ & 6 \\
\hline
\end{tabular}

For solar district heating plants, the solar collectors can be installed on roofs or mounted on the ground. Previous research and case studies showed that the installation cost on roofs is $50 \%$ higher than on the ground[43] and the required solar collector area surpasses the total roof area in a village. Therefore it is assumed in the study that solar collectors are installed on the ground.

Based on the solar district heating guidelines[44], the cost of solar collectors per $\mathrm{m}^{2}$ (including equipment, labor cost and component, etc.) can be estimated by the curve shown in Figure 1 and the heat loss per km distance between collector field and heating station can be estimated by the curve shown in Figure 2 . 


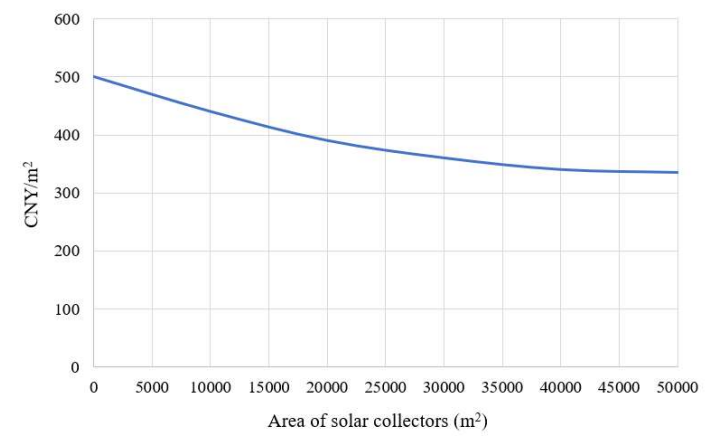

Figure 1 Costs of ground-mounted solar collector field per $m^{2}$ collector installed (source [43])

The curve in Figure 1 was derived from the report[43]. The costs of solar collectors were adjusted with their localized price in China. The curve in Figure 1 can be expressed by Equation 1:

$I_{S C}=p_{F P C} \cdot\left(1-1.652 \times 10^{-5} S+2.26 \times 10^{-10} S^{2}-5.738 \times 10^{-1} S^{3}\right)$, Equation 1

Where, $p_{F P C}$ is the price of flat plate solar collectors made in China, CNY $/ \mathrm{m}^{2} ; I_{s c}$ is the cost of solar collectors, CNY; $S$ is the solar collector area, $\mathrm{m}^{2}$.

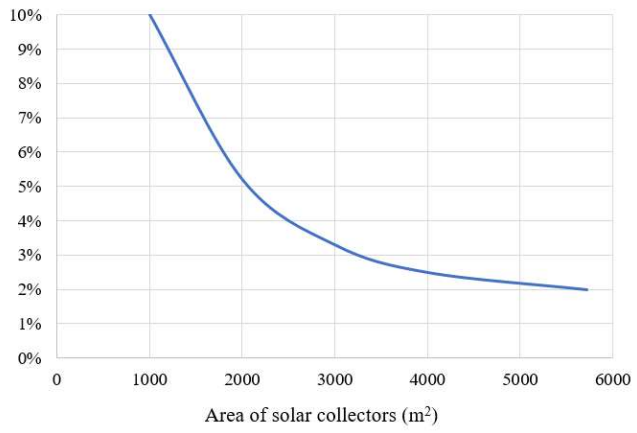

Figure 2 Pipe heat loss per $\mathrm{km}$ to collector output ratio (source [43])

The curve in Figure 2 was derived from the report[44]. However, the horizontal axis was changed from land area to collector area based on the assumption that $3.5 \mathrm{~m}^{2}$ of land is used per $\mathrm{m}^{2}$ of a collector. The curve in Figure 2 can be expressed by Equation 2:

$H_{l}=0.1+8.434 \times 10^{-6} S-2.966 \times 10^{-8} S^{2}+8.747 \times 10^{-12} S^{3}-7.491 \times 10^{-16} S^{4}$, Equation 2

Where $H_{l}, \%$, is the percentage ratio of the pipe heat loss and collector field output.

\subsubsection{Economic assessment}

Levelized cost of heat $(\mathrm{LCOH})$ will be used as the indicator to evaluate the economic performance of different solar district heating systems. The definition of $\mathrm{LCoH}$ recommended by IEA Task 54[17] is shown in Equation 3:

$$
L C o H=\frac{I_{0}-S_{0}+\sum_{t=1}^{T} \frac{C_{t}(1-T R)-D E P_{t} \cdot T R}{(1+r)^{t}}-\frac{R V}{(1+r)^{T}}}{\sum_{t=1}^{T} \frac{E_{t}}{(1+r)^{t}}} \text { Equation } 3
$$

Where, $\mathrm{LCoH}$ is the levelized cost of heat in CNY / $\mathrm{kWh} ; I_{0}$ is the initial investment for the whole system in CNY; $S_{0}$ is subsidies and incentives in CNY; $C_{t}$ is operation and maintenance costs (in yeart) in CNY; TR is the tax rate in \%; $D E P_{t}$ is the asset depreciation (year $\mathrm{t}$ ) in $\mathrm{CNY} R V$ is the residual value of the system in CNY; $E_{t}$ 
is saved final energy (in year $\mathrm{t}$ ) in $\mathrm{kWh} ; r$ is the discount rate in \%. The discount rate is defined as the weighted average cost of capital (WACC). For a district heating system, the owner usually obtains a loan from a bank for the equipment purchase and construction, in this case, the discount rate means the time cost of the money. According to the National Bureau of Statistics of China, 3\% discount rate was used in the study. $T$ is the period of analysis in a year.

Since the purpose of this study is to compare the economic performance of solar district heating systems with different auxiliary heating technologies, the $\mathrm{LCOH}$ means the overall levelized cost of the heat generated by the complete system. Therefore, the value $E_{t}$ is equal to the heating load of the benchmark load model described in 2.1.1.

$$
E_{t}=Q_{t} \text { Equation } 4
$$

Where $Q_{t}$ is the total heat demand of the benchmark load model in year $\mathrm{t}, \mathrm{kWh}$. For a solar district heating system, a large solar collector area needs to be installed, the land rent $p_{\text {land }}, \mathrm{CNY} /$ year should be counted into the calculation as part of the operation fee. Then Equation 3 will evolve into Equation 5 :

$$
L C o H=\frac{I_{0}-S_{0}+\sum_{t=1}^{T} \frac{\left(C_{t}+p_{\text {land }}\right)}{(1+r)^{t}}-\frac{R V}{(1+r)^{T}}}{\sum_{t=1}^{T} \frac{Q_{t}}{(1+r)^{t}}} \text { Equation } 5
$$

\subsubsection{The solar collector area [14]:}

Since the total energy demand of the load model is given, the solar contribution can be calculated as the product of the total energy demand and the solar fraction (SF). The corresponding solar collector area for a given solar fraction (SF) can be obtained by the energy contribution of solar collectors divided by the estimated energy output per $\mathrm{m}^{2}$ solar collector area.

To Improve the calculation accuracy, the quasi-dynamic test (QDT) method defined by ISO 9806[45] was used to calculate the hourly heat production per $\mathrm{m}^{2}$ of solar collectors under specific boundary conditions, as shown in Equation 6[46][47][48][49]:

$$
q_{t}=\eta_{0} G_{b} K_{\theta, b}+\eta_{0} G_{d} K_{\theta, d}-a_{1}\left(t_{m}-t_{a}\right)-a_{2}\left(t_{m}-t_{a}\right)^{2} \text { Equation } 6
$$

Variables in Equation 6: $q_{t}$ is the instantaneous heat production per $\mathrm{m}^{2}$ of solar collectors in $\mathrm{W} / \mathrm{m}^{2} ; \eta_{0}$ is the peak collector efficiency,-; $K_{\theta, d}$ is incidence angle modifier for diffuse solar radiation,-; $K_{\theta, b}$ is incidence angle modifier for beam solar radiation,-; $\theta$ is the incidence angle for radiation in ${ }^{\circ} ; a_{1}$ is the heat loss coefficient of collector at ambient temperature in $\mathrm{W} / \mathrm{m}^{2} \mathrm{~K} ; a_{2}$ is the temperature dependence of the heat loss coefficient of the collector in $\mathrm{W} / \mathrm{m}^{2} \mathrm{~K}^{2} ; t_{m}$ is the mean solar collector fluid temperature in ${ }^{\circ} \mathrm{C}$; $t_{a}$ is the ambient temperature in ${ }^{\circ} \mathrm{C} ; G_{b}$ is beam solar radiation in the collector plane in $\mathrm{W} / \mathrm{m}^{2} ; G_{d}$ is diffuse solar radiation in the collector plane in $\mathrm{W} / \mathrm{m}^{2}$.

The energy output per $\mathrm{m}^{2}$ of collectors at the preset temperature $t_{m}$ is equal to the sum of the heat output of all time steps in the heating season. Therefore the solar collector area can be calculated by Equation 7:

$$
S=\frac{S F \cdot Q_{t}}{\sum \tau \cdot q_{t}} \text { Equation } 7
$$

Where $\tau$ is the time step in one hour; $S$ is the total solar collector area in $\mathrm{m}^{2}$.

\subsection{Calculation process}

The calculation process is shown in Figure 3: 


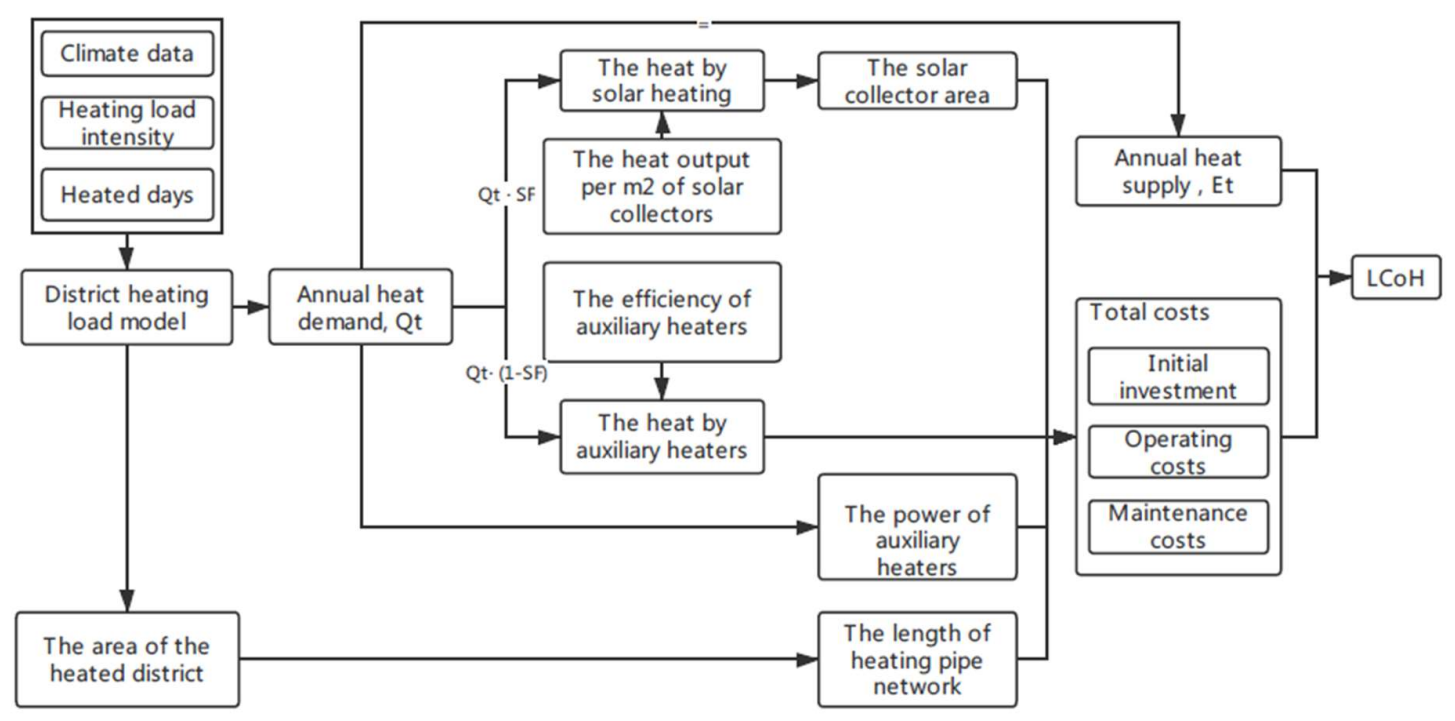

Figure 3 The calculation process of $\mathrm{LCOH}$ for solar district heating systems

In Figure 3, SF is the solar fraction of a given heat load. The value of SF varies in between 0 to 1 . When SF is 0 , the auxiliary heating equipment will cover the full heating load and there is no installation of solar collectors. When SF is 1, solar thermal covers the full heating load, the auxiliary heating equipment does not run, but still needs to be installed for the security of energy supply. Due to the instability and uncertainty of solar energy resources, the rated power of all types of auxiliary heat sources (heat pumps, gas boilers, etc.) in this study is determined based on the maximum heating load of the system.

Due to a large number of variables in this study such as meteorological parameters, heating load, electricity price, gas price, equipment price, equipment efficiency, performance curve, supply and return water temperature of heating terminal units, etc., a considerable number of calculations are needed. Therefore a calculation program using Python language has been developed. With performance characteristics of each device, climate and economic data of typical cities and heating terminal units as inputs, the program calculates $\mathrm{LCOH}$. The $\mathrm{LCOH}$ curve of each solar district heating system is then drawn.

\subsection{Scenarios}

Five scenarios were calculated in order to investigate the influence of heating terminal units, heating load intensity, heated area and land rent on the heating costs. The parameters used in the investigations are shown in Table 3. In the reference scenario (the business as usual scenario, BAU), a village in Beijing with a heated area of $20,000 \mathrm{~m}^{2}$ was investigated. The heating load intensity was $42.9 \mathrm{~W} / \mathrm{m}^{2}$ covered by means of floor heating.

Table 3 The five scenarios for the levelized cost of heat calculations in a district heating project

\begin{tabular}{lllll}
\hline \multirow{2}{*}{$\begin{array}{l}\text { Scenarios } \\
\text { Reference, BAU }\end{array}$} & $\begin{array}{l}\text { Heating terminal } \\
\text { units }\end{array}$ & $\begin{array}{l}\text { Design heating load } \\
\text { intensity, } \mathrm{W} / \mathrm{m}^{2}\end{array}$ & $\begin{array}{l}\text { Heated area, } \mathrm{m}^{2} \\
\mathrm{CNY} / \mathrm{m}^{2} \mathrm{a}\end{array}$ \\
\hline \multirow{2}{*}{$\begin{array}{l}\text { Heating terminal } \\
\text { units, HTS }\end{array}$} & Fadiator & $42.9[50]$ & 20,000 & 0 \\
\cline { 2 - 5 } & Fan coil & 42.9 & 20,000 & 0 \\
\cline { 2 - 5 } & Capillary tube & 42.9 & 20,000 & 0 \\
\hline
\end{tabular}




\begin{tabular}{lllll}
\hline \multirow{2}{*}{$\begin{array}{l}\text { Heating load } \\
\text { intensity, HLS }\end{array}$} & Floor heating & $105[26]$ & 20,000 & 0 \\
\cline { 2 - 5 } & Floor heating & $15[51]$ & 20,000 & 0 \\
\hline \multirow{2}{*}{ Heated area, HAS } & Floor heating & 42.9 & 80,000 & 0 \\
\cline { 2 - 5 } Land rent, LRS & Floor heating & 42.9 & 200,000 & 3 \\
\cline { 2 - 5 } & Floor heating & 42.9 & 20,000 & 60 \\
\hline
\end{tabular}

LRS scenarios investigate the influence of land rent on the heating cost LCoH. Land rental price is generally higher closer to urban areas and lower in rural areas. Since the land in China is state-owned, the land cost could be zero, especially for non-commercial heating systems and for heating systems considered as infrastructure by the local government. A typical annual land rent price could be as low as $3 \mathrm{CNY} / \mathrm{m}^{2}$ for rural area and as high as $60 \mathrm{CNY} / \mathrm{m}^{2}$ for urban CBD area. Therefore, a land rent of 0, 3 and $60 \mathrm{CNY} / \mathrm{m}^{2}$ per year is investigated in this study in order to take account of the varying land price in China. The land area required for a solar collector field is calculated by $3.5 \mathrm{~m}^{2}$ of land per $1 \mathrm{~m}^{2}$ of solar collectors.

\subsection{Boundary conditions}

\subsubsection{Climate data}

The hourly Chinese Standard Weather Data (CSWD)[52] of Beijing will be used in the dynamic calculation. The key meteorological parameters, electricity prices and gas prices of Beijing are listed in Table 4. Hourly outdoor temperature, hourly heating load and hourly solar radiation during the heating period were used in the calculations. The hourly heating load was determined by weighting based on degree days. An average of the outdoor temperature, the heating load and of the solar radiation are presented in Table 4.

Table 4 The key climate data and the energy prices of Beijing

\begin{tabular}{lll}
\hline Items & Value & Unit \\
\hline The average outdoor temperature during the heating period[53] & -1.5 & ${ }^{\circ} \mathrm{C}$ \\
\hline The average solar radiation during the heating period[53] & 11.38 & $\mathrm{MJ} / \mathrm{m}^{2}$ day \\
\hline The average daily hours of sunshine during the heating period [14] & 6.0 & $\mathrm{~h} / \mathrm{day}$ \\
\hline The collector tilt & 40 & \\
\hline The design heating load intensity [50] & 42.9 & $\mathrm{~W} / \mathrm{m}^{2}$ \\
\hline Number of heating days[50],[54] & 121 & $\mathrm{day}$ \\
\hline Gas price & 2.5 & $\mathrm{CNY} / \mathrm{m}^{3}$ \\
\hline Electricity price[55] & 0.538 & $\mathrm{CNY} / \mathrm{kWh}$ \\
\hline
\end{tabular}

2.5.2. System price and performance parameters

1) System price and service life

Table 5 The price and service life for the heat source equipment

\begin{tabular}{llll}
\hline Types & Price & Unit & Service life, Year \\
\hline Flat pate solar collectors, FPC & 500 & $\mathrm{CNY} / \mathrm{m}^{2}$ & 15 \\
\hline Air source heat pump, ASHP & 1500 & $\mathrm{CNY} / \mathrm{kW}$ & 15 \\
\hline Ground source heat pump, GSHP & 3500 & $\mathrm{CNY} / \mathrm{kW}$ & 25 \\
\hline Gas boiler, GB & 190 & $\mathrm{CNY} / \mathrm{kW}$ & 10 \\
\hline Solar heat storage, SHS & 138 & $\mathrm{CNY} / \mathrm{m}^{3}$ & 25 \\
\hline
\end{tabular}

All price information listed in Table 5 is from the Alibaba procurement platform and was verified with the leading manufacturers[56]. The cost of the heat storage was estimated based on an unit of a storage volume 
at $138 \mathrm{CNY} / \mathrm{m}^{3}$.

2) System efficiency and power

Table 6 The system efficiency and power of the heat source equipment

\begin{tabular}{|c|c|c|}
\hline Types & Efficiency equation / value & Power, kW \\
\hline FPC & $\begin{array}{l}\eta=\eta_{0}-a_{1}\left(t_{m}-t_{a}\right) / G-a_{2}\left(t_{m}-t_{a}\right)^{2} / G \\
\eta_{0}=0.717, a_{1}=3.472, a_{2}=0.015\end{array}$ & - \\
\hline ASHP & $\begin{array}{l}C O P_{a}=2.7625+0.0625 T_{\text {eva }}, T_{\text {eva }} \text {, the evaporation } \\
\text { temperature, }{ }^{\circ} \mathrm{C}[57]\end{array}$ & 1933 \\
\hline GSHP & $\begin{array}{l}C O P_{g}=3.485-0.0625 T_{\text {con }}, T_{\text {con }} \text {, the condensation } \\
\text { temperature, }{ }^{\circ} \mathrm{C}[24] ;\end{array}$ & 1933 \\
\hline GB & $85 \%$ (thermal efficiency) & 5000 \\
\hline SHS & $40 \%$ (the heat recovery efficiency) & - \\
\hline
\end{tabular}

The parameters of efficiency expression for a flat plate solar collector were obtained from the test reports of Chinese collectors available on SolarKeymark. These parameters represent efficiencies of solar collectors commonly used in China. For ASHP and GSHP systems, the COP will change with evaporation temperature and condensation temperature. Individual and collective installations will also influence the annual system efficiency of heat pumps[58]. Table 6 gives empirical equations of COP as a function of evaporation/condensation temperature. A typical non-condensing gas boiler has a thermal efficiency of around $85 \%$. Based on the research findings by Guo[23] and Guo and Goumba[59], a seasonal heat recovery efficiency of $40 \%$ was used for the heat storage.

3) Heating terminal units

Heating terminal units not only directly affect the comfort of space heating but also the system efficiency. Table 7 lists four main types of heating terminal units commonly used in district heating systems in China and their supply/return water temperatures.

Table 7 The assumed supply and return water temperature of different heating terminal units

\begin{tabular}{lll}
\hline Types & Water temperature, Supply / Return, ${ }^{\circ} \mathrm{C}$ & References \\
\hline Radiators & $85 / 60$ & {$[60]$} \\
\hline Floor heating & $50 / 35$ & {$[61]$} \\
\hline Fan coil & $50 / 40$ & {$[62]$} \\
\hline Capillary tube network & $32 / 28$ & {$[63][64][65]$} \\
\hline
\end{tabular}

The supply/return water temperatures are taken from design specifications or guidelines for space heating systems.

\subsubsection{Maintenance and operating costs}

The operating and maintenance costs of the studied systems as a function of solar collector area are listed in Table 8.

Table 8 The system operating and maintenance costs of the heat source equipment

\begin{tabular}{lll}
\hline Types & Operating cost, CNY / a & Maintenance cost, CNY / a \\
\hline FPC & $P_{\text {pump }} \times S_{y} \times d \times S \times p_{e}$ & $0.01 \times p_{F P C} \times S$ \\
\hline ASHP & 1166144 & 28995 \\
\hline
\end{tabular}




\begin{tabular}{lll}
\hline GSHP & 905233 & 67655 \\
\hline GB & 1561252 & 9500 \\
\hline SHS & 1561252 & $0.01 \times 2 \times p_{\text {shs }} \times \mathrm{S}+9500$ \\
\hline
\end{tabular}

Assume that the annual maintenance costs of the system are $1 \%$ of initial investment[66], the annual maintenance costs of the solar collector field can be calculated by the equation $M_{s c f}=0.01 \times I \times S$, where, $p_{F P C}$ is the price of per $\mathrm{m}^{2}$ of flat plate solar collectors, $\mathrm{CNY} / \mathrm{m}^{2}$.

According to research by Liu Meishan[31], Zhang Guangyu[32] and J. Xu[67], the optimum ratio between the volume $\left(\mathrm{m}^{3}\right)$ of the hot water storage pond and the area $\left(\mathrm{m}^{2}\right)$ of the collectors is about 2:1. Therefore, the maintenance cost of heat storage can be calculated by using the equation $M_{\text {shs }}=0.01 \times 2 \times p_{\text {shs }} \times S+$ 9500 , where, $p_{\text {shs }}$ is the price per $\mathrm{m}^{3}$ of heat storage as listed in Table $5, \mathrm{CNY} / \mathrm{m}^{3}, p_{\text {shs }}=138 \mathrm{CNY} / \mathrm{m}^{3} ; 9500$ $\mathrm{CNY}$ is the annual maintenance cost of gas boilers.

The annual maintenance costs for ASHP, GSHP and GB are assumed to be $1 \%$ of the initial investment. Since the powers of these three types of auxiliary heat sources are fixed, the initial investments and maintenance costs can be determined. The data is taken from the market price of the equipment.

For the solar collector field and heat storage, the operating costs are mainly generated by circulation pumps. When the working fluid flow rate is $0.072 \mathrm{~m}^{3} / \mathrm{h}$ per $\mathrm{m}^{2}$ solar collector, the corresponding power for circulation pumps is $12 \mathrm{~W}$ per $\mathrm{m}^{2}$ of collectors. Therefore, power consumption is calculated as $12 \mathrm{~W} / \mathrm{m}^{2}$ [14]. Therefore, the operating cost of the solar collector field can be calculated by the equation $O_{s c f}=P_{\text {pump }} \times$ $S_{y} \times d \times S \times p_{e}$, where, $P_{\text {pump }}$, the power consumption of the circulation pumps, W/m², is $12 \mathrm{~W} / \mathrm{m}^{2} ; S_{y}$ is the average hours per day that pumps are in operation during the heating period, $\mathrm{h} /$ day; $d$ is the number of heating days,-; $p_{e}$ is the price of electricity, CNY / kWh. The operating cost of seasonal heat storage is assumed to be zero.

The operating cost of auxiliary heat sources is calculated based on the heat required by the auxiliary heat source equipment (the difference between the total heat demand and the heat supplied by the solar thermal system) and the price of electricity and gas.

\section{Results}

3.1. Validation of the model

In order to examine the validity of the developed calculation method, four projects reported in the literature or from engineering companies are investigated. The location and source of the projects are listed in Table 9. The Chinese Standard Weather Data was used for the four different locations. The solar fraction and $\mathrm{LCOH}$ are calculated using the developed method and compared to the reported values in the literature. A comparison of the reported $\mathrm{LCOH}$ and the calculated $\mathrm{LCOH}$ is given in Table 9.

Table 9 Reported values and the model predicted values of the four types of solar district heating systems

\begin{tabular}{lllllll}
\hline System types & Location & Source & SF & $\begin{array}{l}\text { Reported LCoH value, } \\
\text { CNY / kWh }\end{array}$ & $\begin{array}{l}\text { LCoH by the model, } \\
\text { CNY / kWh }\end{array}$ & $\begin{array}{l}\text { Relative } \\
\text { Difference }\end{array}$ \\
\hline ST + ASHP & Dingzhou & SunRain & $4 \%$ & 0.352 & 0.334 & $-5 \%$ \\
\hline ST + GSHP & Shaanxi & Tianpu & $16 \%$ & 0.344 & 0.331 & $-4 \%$ \\
\hline ST + GB & Yantai & Sangpu & $52.5 \%$ & 0.335 & 0.388 & $16 \%$ \\
\hline ST + GB + SHS & Beijing & {$[30]$} & $13.6 \%$ & 0.399 & 0.401 & $0.5 \%$ \\
\hline
\end{tabular}


Table 9 shows that the deviations in the $\mathrm{LCoH}$ values between the real cases in different cities and the model developed in this study are lower than $5 \%$ in three cases except for the ST + GB scenario where a relative difference of $16 \%$ is obtained. The reason for the large deviation is that the ST + GB system also includes domestic hot water consumption, which is not considered in the calculations. According to the calculation results of the heating load (HLS) scenarios, as shown in Figure 4 (8), an increase in a system load will result in a decrease of $\mathrm{LCoH}$. Since a load of domestic hot water is not included in the calculations, the model will overestimate the $\mathrm{LCoH}$ value. It can be concluded from Table 9 that the model developed in this study is reliable for the prediction of $\mathrm{LCOH}$ under different boundary conditions. 
3.2. LCoH curves for different scenarios

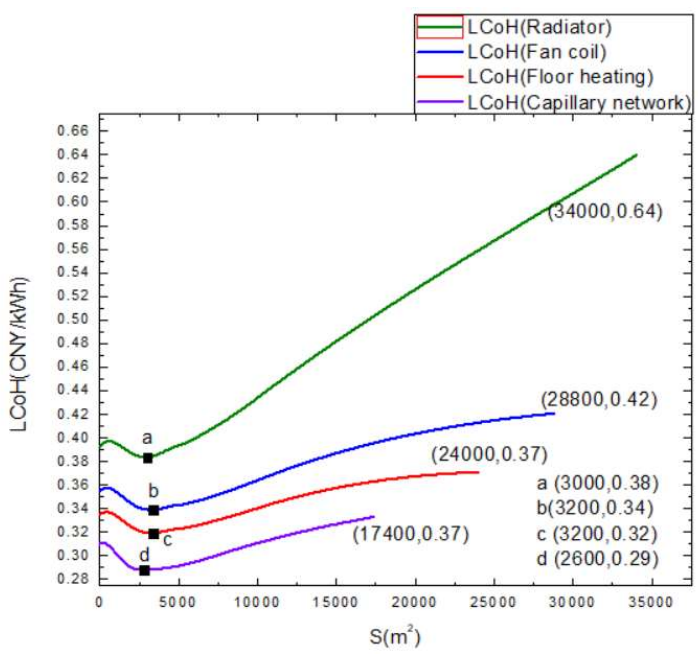

(1) $\mathrm{LCOH}$ curves for ST+ ASHP with different heating terminal units (HTS)

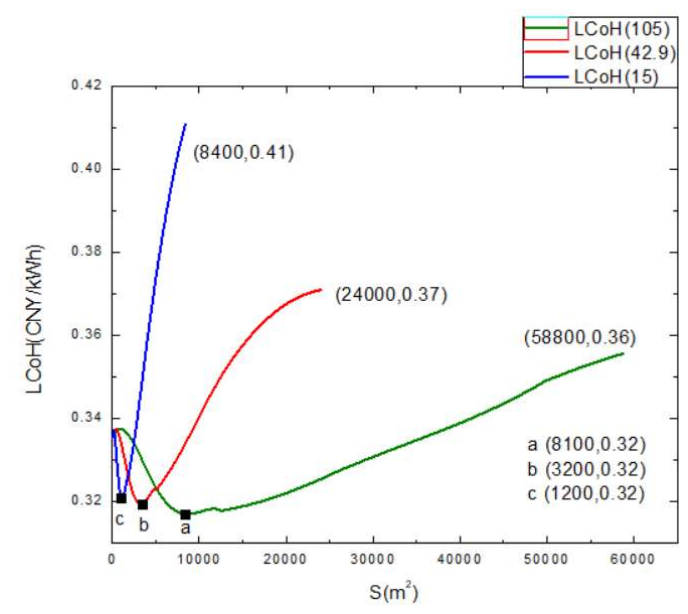

(2) $\mathrm{LCOH}$ curves for ST+ ASHP with different heating load intensities (HLS)

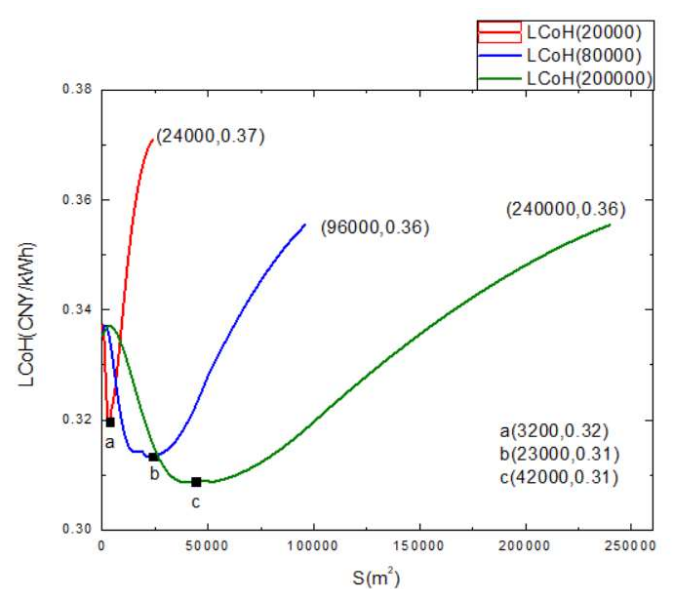

(3) $\mathrm{LCoH}$ curves for ST+ ASHP with different heated areas (HAS) 


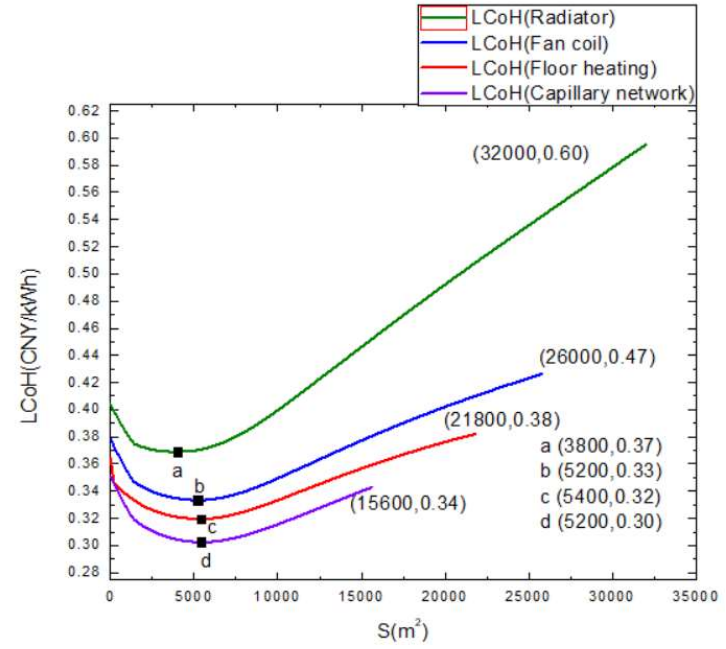

(4) $\mathrm{LCOH}$ curves for ST+ GSHP with different heating terminal units (HTS)

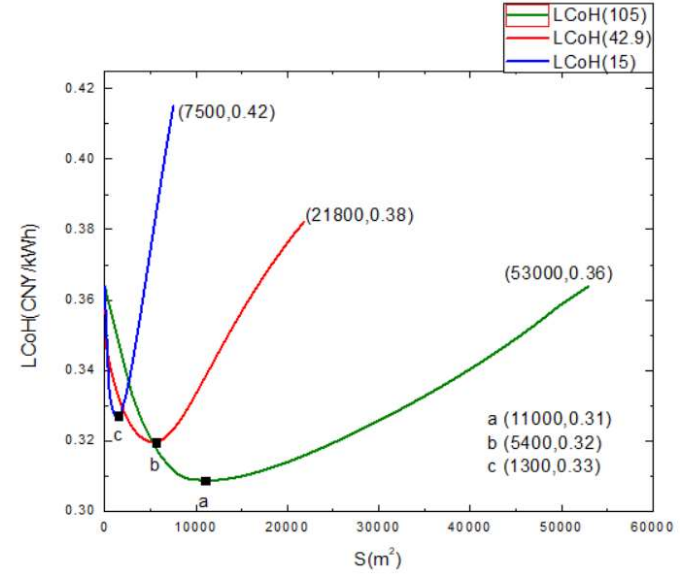

(5) LCoH curves for ST+ GSHP with different heating load intensities (HLS)

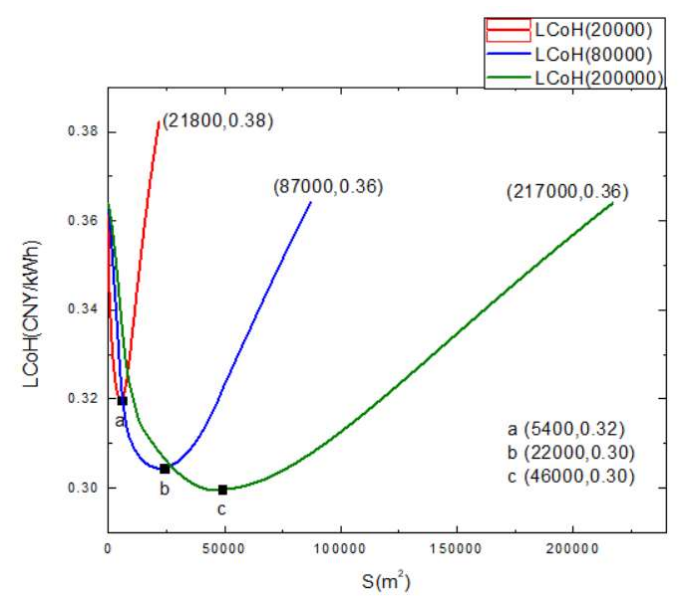

(6) $\mathrm{LCoH}$ curves for ST+ GSHP with different heated areas (HAS)

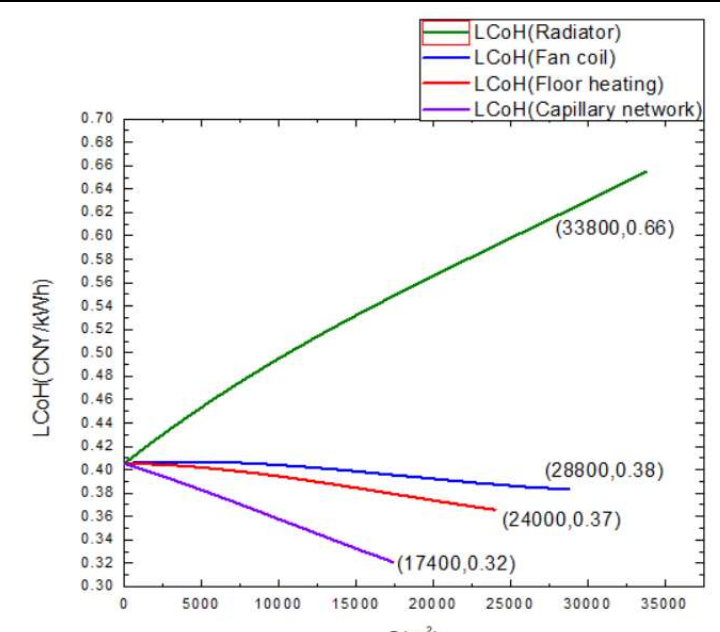

$\mathrm{s}\left(\mathrm{m}^{2}\right)$
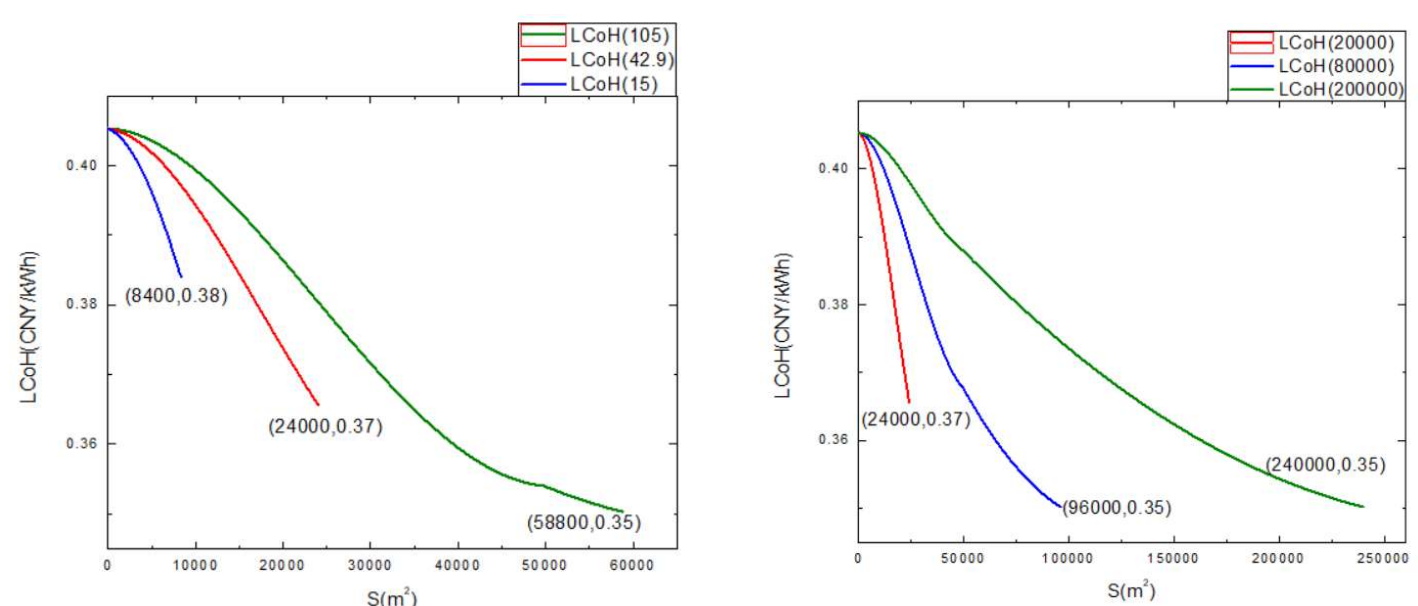


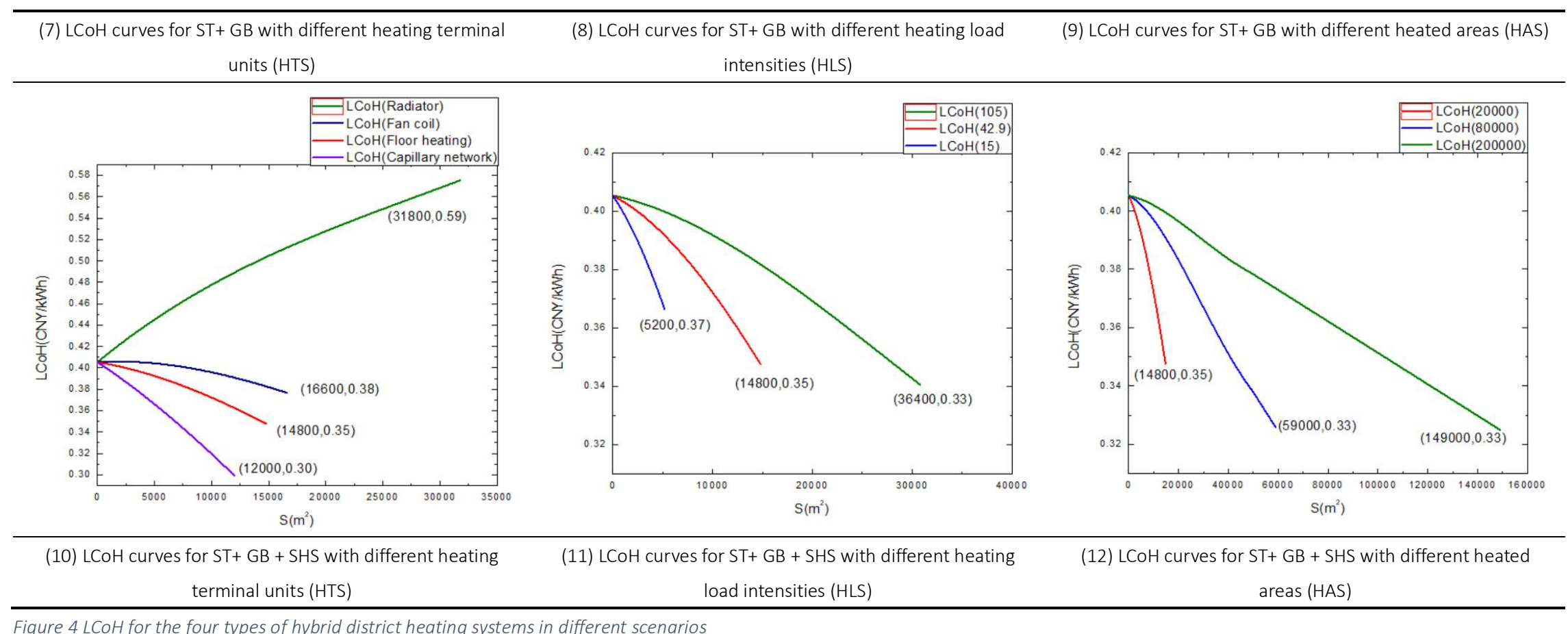

Figure $4 \mathrm{LCOH}$ for the four types of hybrid district heating systems in different scenarios 
A parametric analysis was carried out to investigate the influence of heating terminal units, heating load and heated area on the cost of heat. Figure 4 shows that results of the predicted $\mathrm{LCOH}$ for four types of hybrid district heating systems in different scenarios. In these figures, the $X$-axis represents the solar collector area. The starting point of each curve represents $S F=0$, and the right endpoint represents $S F=1$. Due to the large difference in heating load between different scenarios, there is an order of magnitude of difference in the required solar collector area. In order to show the $\mathrm{LCOH}$ trend, different scales are used in the figures.

Figure 4 (1), (4), (7) and (10) show LCoH versus solar collector area for different types of heating terminal unit. It is shown that with an increase in supply and return water temperatures the $\mathrm{LCOH}$ increases significantly. For heat pump combinations, because the efficiency of heat pumps is strongly affected by supply and return water temperatures, $\mathrm{LCoH}$ curves begin at different points when SF $=0$. When SF is increasing, LCoH curves initially decrease to the lowest points and increase to the endpoints where SF is 1. For gas boiler combinations, because the efficiency of gas boilers is not affected by supply and return water temperatures, $\mathrm{LCoH}$ curves start at the same point when $\mathrm{SF}=0$. When $\mathrm{SF}$ is increasing, $\mathrm{LCoH}$ curves decrease to the endpoints for low-temperature heating terminal units. However, for radiators, the high supply and return water temperature reduces the efficiency of solar collectors, resulting in a lower economic performance of the entire system and a continuous rising $\mathrm{LCOH}$.

Table 10 The lowest $\mathrm{LCOH}$, the corresponding SF and the solar collector area for the heating system with a capillary network as a heating terminal unit

\begin{tabular}{llll}
\hline \multirow{2}{*}{ Systems } & The lowest LCOH & The optimum SF & The solar collector area \\
\cline { 2 - 4 } & CNY / kWh & $\%$ & $\mathrm{~m}^{2}$ \\
\hline ST + ASHP & 0.29 & 15 & 2600 \\
\hline ST + GSHP & 0.30 & 33 & 5,200 \\
\hline ST + GB & 0.32 & 100 & 17,400 \\
\hline ST + GB + SHS & 0.30 & 100 & 12,000 \\
\hline
\end{tabular}

The capillary network results in the lowest $\mathrm{LCOH}$ in all four systems investigated in the heating terminal (HTS) scenarios. Table 10 shows the lowest $\mathrm{LCOH}$ and the corresponding SF and solar collector area for the heating system with the capillary network. The result shows that the combination of ST + ASHP gives the lowest $\mathrm{LCOH}$ and requires a smaller solar collector area than the combination of ST + GSHP. For the combinations of $\mathrm{ST}+\mathrm{GB}$ and $\mathrm{ST}+\mathrm{GB}+\mathrm{SHS}$, a larger solar collector area always results in lower $\mathrm{LCoH}$. When the areas of solar collectors reach 17,400 $\mathrm{m}^{2}(\mathrm{ST}+\mathrm{GB})$ and $12,000 \mathrm{~m}^{2}(\mathrm{ST}+\mathrm{GB}+\mathrm{SHS})$, the SFs of the both systems reach $100 \%$. It should be noted that for a solar fraction of $100 \%$, the auxiliary heating system does not run but the cost of the auxiliary heating system is included in the total investment of the heating system. The LCoHs reach the lowest points, $0.32 \mathrm{CNY} / \mathrm{kWh}$ and $0.30 \mathrm{CNY} / \mathrm{kWh}$ respectively, but they are still higher than the $\mathrm{LCOH}$ of the combination of ST + ASHP, $0.29 \mathrm{CNY} / \mathrm{kWh}$.

Figure 4 (2, 5, 8 and 11) show LCoH versus solar collector area for different heating load intensity. The results show that with an increase in heating load intensity, the $\mathrm{LCOH}$ increases for all combinations before the heat pump combinations reach the lowest points with the same solar fraction. Once the lowest point is crossed, with an increase of solar fraction, the $\mathrm{LCOH}$ of the heat pump combinations increases quickly for lower heating load intensity and slowly for higher heating load intensity. The lowest LCOH for high heating load intensity is even lower than that for low heating load intensity, which means that the higher the heating 
load intensity, the larger the economic benefits contributed by solar thermal will be. Taking the combination of ST + ASHP as an example, when the load is $105 \mathrm{~W} / \mathrm{m}^{2}$, the lowest point of $\mathrm{LCOH}$ is $0.32 \mathrm{CNY} / \mathrm{kWh}$, which is $6 \%$ lower than the start point of $0.34 \mathrm{CNY} / \mathrm{kWh}$ (single heat source). When the load is $15 \mathrm{~W} / \mathrm{m}^{2}$, the lowest point of $\mathrm{LCOH}$ is 0.32 , a decrease of $4 \%$ compared to the starting point.

Table 11 The lowest LCOH, the corresponding SF and the solar collector area with a heating load intensity of $105 \mathrm{~W} /$ $m^{2}$

\begin{tabular}{llll}
\hline \multirow{2}{*}{ Systems } & The lowest LCoH & The optimum SF & The solar collector area \\
\cline { 2 - 4 } & CNY / kWh & $\%$ & $\mathrm{~m}^{2}$ \\
\hline ST + ASHP & 0.32 & 11 & 8100 \\
\hline ST + GSHP & 0.31 & 31 & 11000 \\
\hline ST + GB & 0.35 & 100 & 58000 \\
\hline ST + GB + SHS & 0.33 & 100 & 36400 \\
\hline
\end{tabular}

Table 11 shows the lowest $\mathrm{LCOH}$ of the four systems with a heating load intensity of $105 \mathrm{~W} / \mathrm{m}^{2}$. In this case, the combination of ST + GSHP provides the lowest $\mathrm{LCoH}$ and a SF of 31\%.

Figure 4 (3), (6), (9) and (12) show $\mathrm{LCoH}$ versus solar collector area for different heated area. With an increase in the heated area, the $\mathrm{LCOH}$ increases for all combinations before the heat pump combinations reach the lowest point with the same SF. Once the lowest point is crossed, the LCoH of the heat pump combinations increases quickly for the less heated area and slowly for the more heated area with SF increasing. The lowest $\mathrm{LCoH}$ for the more heated area is lower than that for a less heated area, which means the larger the heated area, the larger the economic benefits contributed by solar thermal will be. Taking the combination of ST + ASHP as an example, when the heated area is $200,000 \mathrm{~m}^{2}$, the lowest LCoH is 0.31 $\mathrm{CNY} / \mathrm{kWh}$, which is $8 \%$ lower than the starting point of 0.34 (single heat source). When the heated area is $20,000 \mathrm{~m}^{2}$, the lowest point of $\mathrm{LCOH}$ is $0.32 \mathrm{CNY} / \mathrm{kWh}$, a decrease of $5 \%$ compared to the starting point.

Table 12 The lowest $\mathrm{LCOH}$, the corresponding SF and the solar collector area for a floor area of 200,000 $\mathrm{m}^{2}$

\begin{tabular}{llll}
\hline \multirow{2}{*}{ Systems } & The lowest LCoH & The optimum SF & The solar collector area \\
\cline { 2 - 4 } & CNY / kWh & $\%$ & $\mathrm{~m}^{2}$ \\
\hline ST + ASHP & 0.31 & 17.5 & 42000 \\
\hline ST + GSHP & 0.30 & 30 & 46,000 \\
\hline ST + GB & 0.35 & 100 & 240000 \\
\hline ST + GB + SHS & 0.33 & 100 & 149000 \\
\hline
\end{tabular}

Table 12 shows the lowest $\mathrm{LCoH}$ in the four systems with a floor area of 200,000 $\mathrm{m}^{2}$. In this case, the combination of ST + GSHP results in the lowest LCoH with a SF of $30 \%$ and a solar collectors area of 46,000 $\mathrm{m}^{2}$. To reach the lowest $\mathrm{LCOH}$, the gas boiler combinations require far more solar collectors than the heat pump combinations and the lowest $\mathrm{LCOH}$ is still higher than that of the heat pump combinations.

$\mathrm{LCoH}$ curves of the four systems under the BAU scenario are shown in red in all figures. The curves maintain the same shape for the same system type, although the curves look different because of the different scale in the X-axis (the solar collector area).

In the reference BAU scenario, the SF and the solar collector area with the lowest $\mathrm{LCOH}$ are shown in Table 
13.

Table 13 The SF and the solar collector area with the lowest LCOH for the BAU scenario

\begin{tabular}{llll}
\hline \multirow{2}{*}{ Systems } & The lowest LCoH & The optimum SF & The solar collector area \\
\cline { 2 - 4 } & CNY / kWh & $\%$ & $\mathrm{~m}^{2}$ \\
\hline ST + ASHP & 0.319 & 13 & 3200 \\
\hline ST + GSHP & 0.320 & 32 & 5,400 \\
\hline ST + GB & 0.366 & 100 & 24000 \\
\hline ST + GB + SHS & 0.348 & 100 & 14800 \\
\hline
\end{tabular}

The comparison in Table 13 shows that the combination of solar thermal with ASHP results in the lowest $\mathrm{LCoH}$ with a minimum solar collector area, but with a lower solar fraction. For gas boiler combinations, the heating cost is reduced with an increase in solar fraction. The optimal configurations are systems with $100 \%$ solar fraction. For a gas boiler heating system without seasonal heat storage, a solar collector area of 24000 $\mathrm{m}^{2}$ is needed in order to cover the heat demand entirely by solar heat. With seasonal heat storage, the required solar collector area to achieve a solar fraction of $100 \%$ is reduced to $14800 \mathrm{~m}^{2}$. This shows that seasonal heat storage is beneficial for a solar district heating system with a large share of solar fraction. This result can also be explained by the scale effect. Larger solar collector installation requires large thermal energy storage volume, which in turn results in low-energy loss through insulation[59] and higher system efficiency.

3.3. LCoH curves for different annual land rents

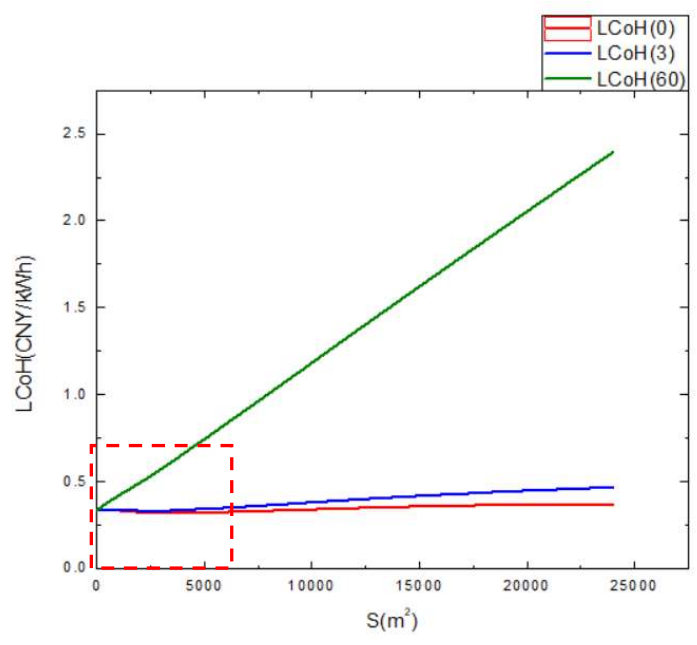

a) The original curves

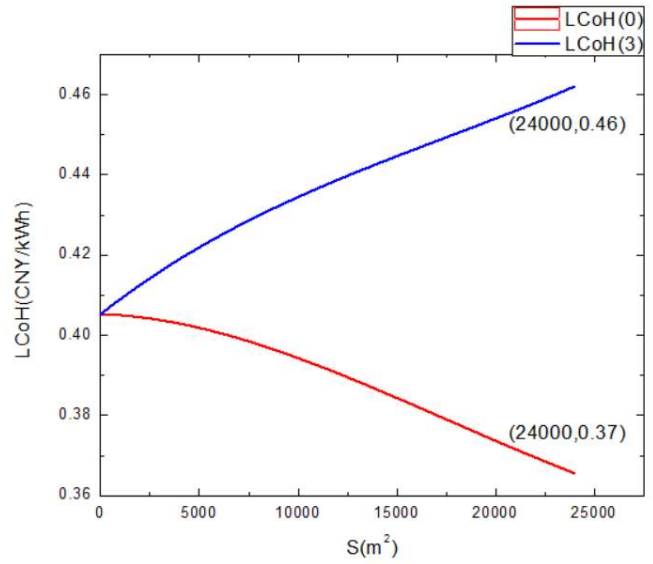

b) A partially enlarged view of the curve inside the dotted red box

Figure 5 The $\mathrm{LCOH}$ curves of ST + ASHP for different land rent costs 


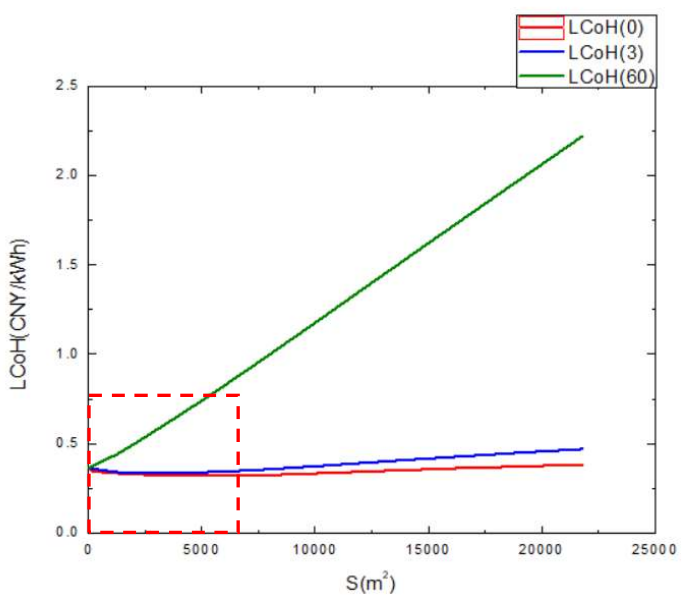

a) The original curves

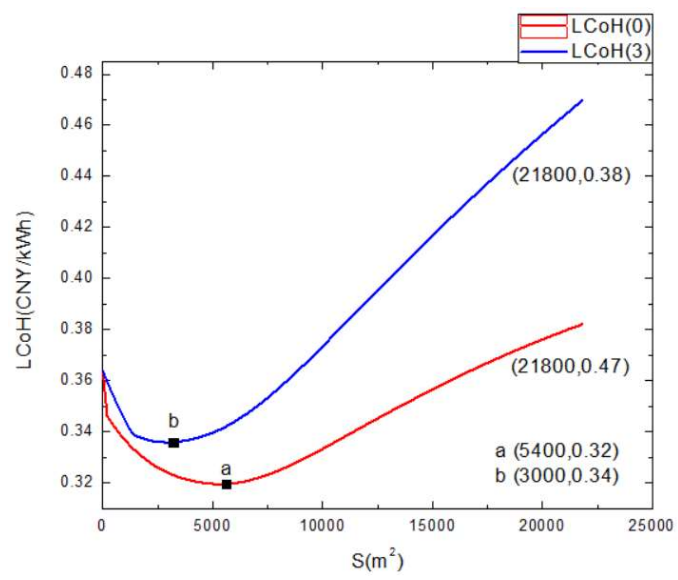

b) A partially enlarged view of the curve inside the dotted red box

Figure 6 The $L C O H$ curves of ST + GSHP for different land rent costs

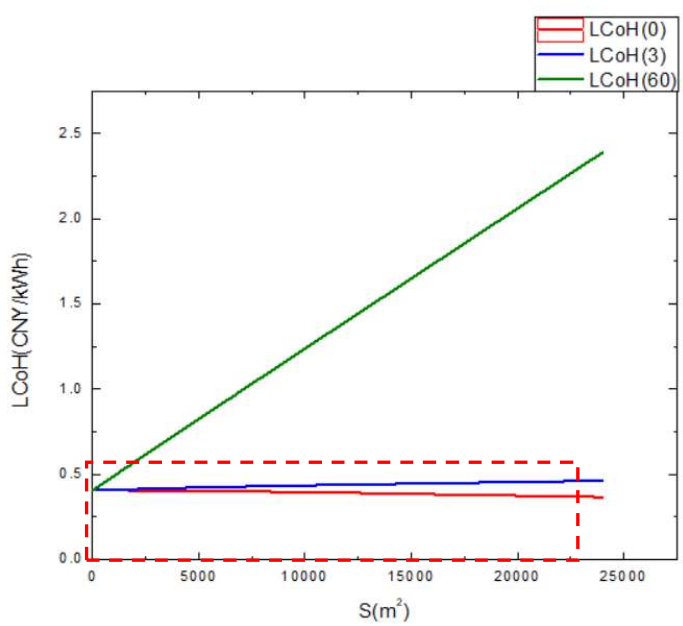

a) The original curves

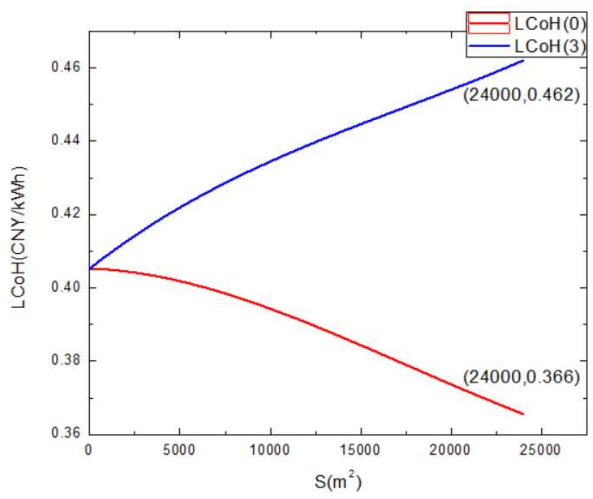

b) A partially enlarged view of the curve inside the dotted red box

Figure 7 The $L C O H$ curves of ST $+G B$ for different land rent costs 


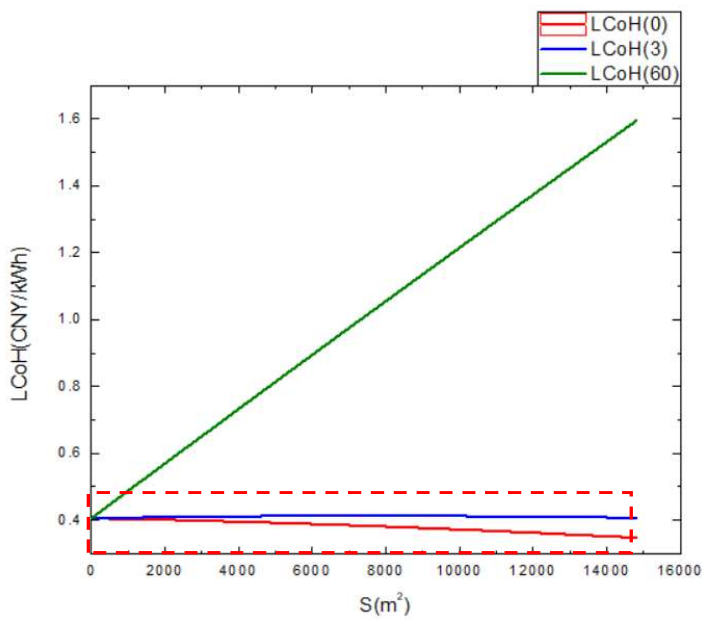

a) The original curves

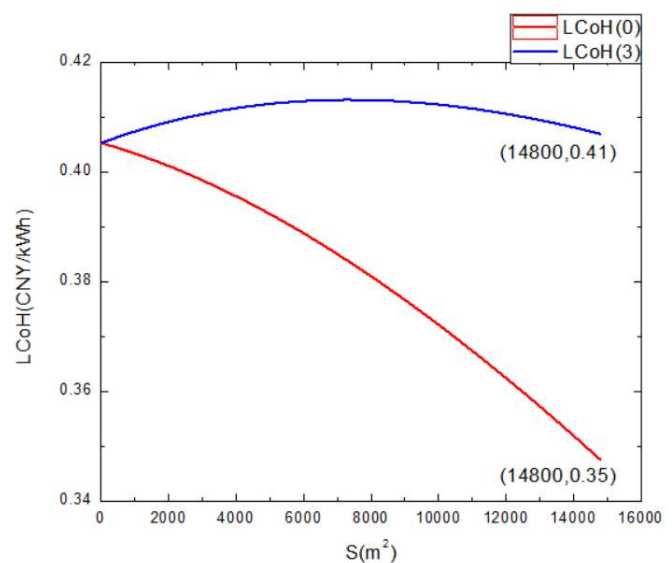

b) A partially enlarged view of the curve inside the dotted red box

Figure 8 The $L C O H$ curves of ST $+G B+S H S$ for different land rent costs

Figure 5 to Figure 8 show that land rent can significantly affect LCoH in all the investigated systems. As the land rent increases, the economic benefits that solar thermal brings to the system gradually decrease until a solar heating system becomes an economic disadvantage.

When the land price is higher than $60 \mathrm{CNY} / \mathrm{m}^{2}$, the LCoH curves of the four systems increase rapidly with an increase in solar collector area, as shown by the green curves in Figure 5 (a), Figure 6 (a), Figure 7 (a) and Figure 8 (a). A solar heating system does not seem to be beneficial. The curves show that solar district heating technology is not suitable for areas with high land prices, for example, in urban cities.

However, when the land price is low, such as $3 \mathrm{CNY} / \mathrm{m}^{2}$ or zero, $\mathrm{LCoH}$ curves of the heat pump combinations have inflection points, where the $\mathrm{LCOH}$ is at its lowest point. For the gas boiler combinations, $\mathrm{LCoH}$ will gradually decrease with an increase in the solar collector area and will reach the minimum value until the SF reaches $100 \%$.

\section{Discussion}

4.1. Limitations

For the combination of solar thermal and GSHP, this study obtained the most suitable solar collector area from an economic point of view. However, in reality, there is an issue of the annual energy balance of the ground. In winter, heat is extracted from the ground by the GSHP, resulting in a decreased soil temperature. The missing heat should be supplemented by the surplus of solar heat produced by the collectors in seasons with low heat demand. Therefore, an appropriate solar collector area is necessary in order to be able to ensure the energy balance of the ground.

\subsection{Discussion of results}

In this study, only the space heating load in winter was considered, while the heating load for domestic hot water was not included. Presently, the district heating systems in China only runs during the heating season, while they are idle for the rest of the year. The district heating system is not designed for domestic hot water 
services. At the same time, heating companies in China are generally heavily subsidized. Take Beijing as an example, the real heat price for residents is $30 \mathrm{CNY} / \mathrm{m}^{2}$, or $0.16 \mathrm{CNY} / \mathrm{kWh}[68]$. The heating price is even lower than the lowest LCoH of $0.32 \mathrm{CNY} / \mathrm{kWh}$ in the reference BAU scenario illustrated in Table 13. The current heating price is not enough to cover all expenses of a district heating company. If the district heating network is also used as a heat source for domestic hot water and a solar heating system is added to the heating plant, the heating price could be reduced as indicated by the heating load HLS scenarios. To verify this hypothesis, a calculation is conducted in the following:

The average daily heat consumption of hot water can be calculated by the following Equation 8:

$$
Q_{W}=n \cdot q_{r} \cdot c_{w} \cdot \rho_{w} \cdot\left(t_{h}-t_{c}\right) / 86400 \text { Equation } 8
$$

Where, $n$ is the number of hot water use per unit, e.g., people or beds; $q_{r}$ is the hot water consumption, according to the "Design Code for Building Water Supply and Drainage"(GB0015), L/ person·day; $c_{w}$ is the specific heat capacity of water, $4180 \mathrm{~J} / \mathrm{kg} \cdot \mathrm{K} ; \rho_{w}$ is the density of hot water, $\mathrm{kg} / \mathrm{L} ; t_{h}$ is the hot water temperature, ${ }^{\circ} \mathrm{C} ; t_{c}$ is the cold water temperature, ${ }^{\circ} \mathrm{C}$.

When the domestic hot water consumption is $45 \mathrm{~L} /$ person-day[69],[70], the hot water temperature is $45^{\circ} \mathrm{C}$, the hot water density is $0.99 \mathrm{~kg} / \mathrm{L}$ and the cold water temperature is $5{ }^{\circ} \mathrm{C}$, the heating load of a threeperson household is calculated as $259 \mathrm{~W}$ by the Equation 8. It should be noted that the hot water temperature of $45^{\circ} \mathrm{C}$ is used merely to determine daily hot water energy consumption. Supply temperature for domestic hot water is typically higher, for instance $60-65^{\circ} \mathrm{C}$.

Based on the model and the calculation process described in chapter 2, LCoH curves are drawn in Figure 9 when domestic hot water load is also covered and is given priority by a district heating system.

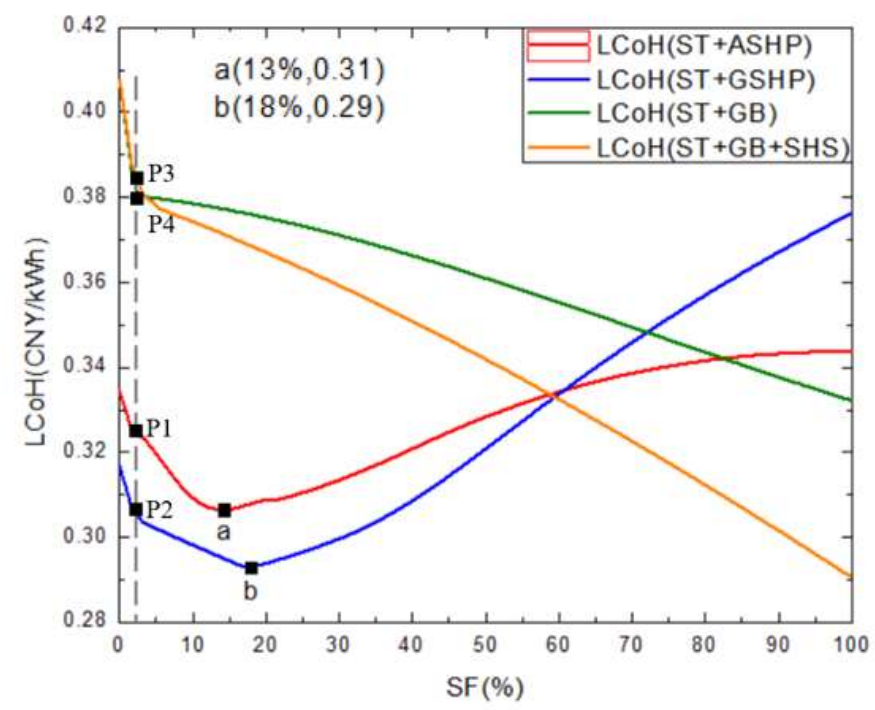

Figure $9 \mathrm{LCOH}$ curves of the reference BAU Scenario with the domestic hot water load included

Figure 9 shows that the lowest LCoH can be reduced to 0.29 CNY / kWh in the reference BAU scenario, 8\% lower than the system without domestic hot water load. If heating companies charge hot water fees, it can effectively improve their financial benefit. 
There is a minor difference between LCoH curves in Figure 9 and the curves in Figure 4 (1) to (12). There are inflection points $\left(p_{1}, p_{2}, p_{3}\right.$, and $p_{4}$ in Figure 9$)$ before $\mathrm{LCoH}$ curves reach their lowest points. When $\mathrm{SF}<$ $2.4 \%, \mathrm{LCoH}$ rapidly decreases before domestic hot water loads are fully covered by solar thermal. Once solar thermal covers all domestic hot water load (SF $\geq 3 \%$ ), LCoH reduces slowly.

Biomass boilers are used as a significant substitution for coal boilers in Denmark and other European countries. However, in China, biomass boilers are not popular at present due to the lack of a stable and reliable biomass source. Figure 10 shows $\mathrm{LCoH}$ curves when a biomass boiler is used as a heat source in a district heating system. The price of wood pellet changes from $700 \mathrm{CNY}$ / ton to $1400 \mathrm{CNY}$ / ton. The calorific value of a wood pellet is $17.2 \mathrm{GJ} / \mathrm{ton}$. As can be seen from Figure 10, if the price of wood pellets is lower than $1100 \mathrm{CNY}$ / ton, LCOH increases with a higher SF for the combination of solar thermal with biomass boilers. Only when the price of the wood pellet is higher than $1100 \mathrm{CNY} /$ ton, can the solar thermal system reduce $\mathrm{LCOH}$.

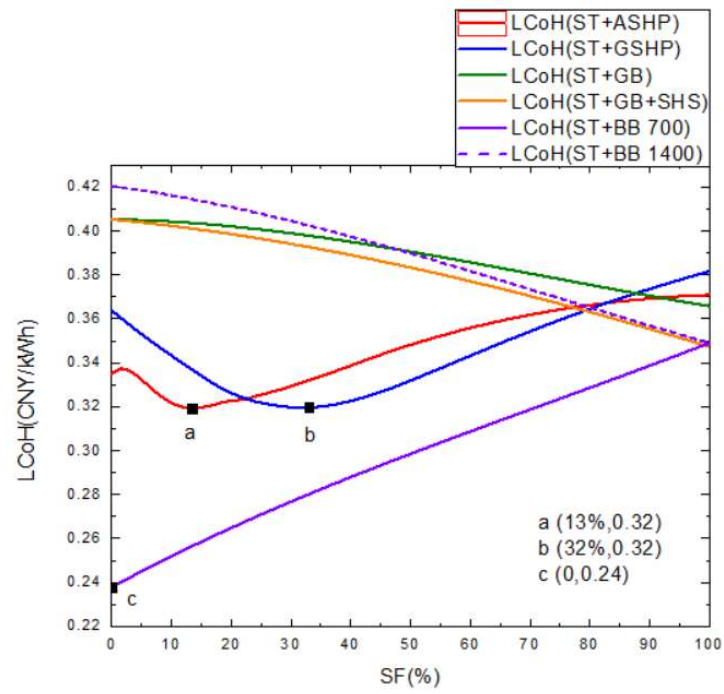

Figure $10 \mathrm{LCOH}$ curves of the reference BAU scenario with a combination of solar thermal and biomass boilers and with different prices of wood pellet.

\subsection{Future work}

Firstly, it should be pointed out that the focus of this study is on economic analysis of different combinations of solar heating with various heat sources. The purpose of the investigations is to understand the suitability of solar district heating under different technical combinations. However, in engineering projects, there are more combinations. Such as the combination of gas boilers and heat pumps, the combination of biomass boilers, large-scale heat storage facilities, heat pumps, and organic Rankine cycle cogeneration systems, the combination of waste heat utilization and heat pumps in waste incineration power plants and the combination of large-scale photovoltaic power plants and heat pumps, etc.. In-depth research is needed to investigate how to match the various energy sources in these systems to achieve the best economical solutions.

Further, this study only considers economics and does not consider the environmental impact of each technology portfolio (global warming potential, $\mathrm{CO}_{2}$ emission, $\mathrm{SO}_{2}$ emission, and $\mathrm{PM}_{10}$ emission, etc. ). 
$\mathrm{CO}_{2}$ emission reduction and primary energy saving were discussed in the preliminary study. However, these two indicators increased with an increase in solar collector installation, it would make no sense for the decision makers. Combining environmental impact with economic evaluation, the best combination of environmental and economic benefits can be found by multiple objective optimization methods.

5. Conclusions

The levelized cost of heat ( $\mathrm{LCOH}$ ) was calculated for solar district heating systems in combinations with air source heat pumps (ASHP), ground source heat pump (GSHP) and gas boiler (GB). Based on these calculations, the trend of $\mathrm{LCOH}$ with the solar collector area under different heating load intensities, heating terminal units, heated areas and land rents is discussed. The optimal solar collector area and the solar fraction are determined. The results show that:

1) LCoH does not necessarily decrease in a solar district heating system with an increase in SF. When heat pumps are used as an auxiliary heat source, there is an optimal SF (11\%-33\%) when LCoH reaches the lowest point. When gas boilers are used as an auxiliary heat source, LCoH decreases in a lowtemperature heating network (Supply $\leqslant 50{ }^{\circ} \mathrm{C}$, Return $\leqslant 40{ }^{\circ} \mathrm{C}$ ) to the lowest point when SF is $100 \%$; LCoH increases in a high-temperature heating network (Supply $\geqslant 85^{\circ} \mathrm{C}$, Return $\geqslant 60^{\circ} \mathrm{C}$ ).

2) For a solar district heating system with seasonal heat storage, the higher the SF, the lower the LCoH in a low-temperature heating network (Supply $\leqslant 50^{\circ} \mathrm{C}$, Return $\leqslant 40^{\circ} \mathrm{C}$ ). The seasonal heat storage can maximize advantages of solar thermal when gas boilers are used as an auxiliary heat source and the advantages of solar thermal are not significant when heat pumps are used as an auxiliary heat source.

3) The higher the heat demand is, the larger the economic benefits contributed by solar thermal will be. For the Chinese heating industry, if the district heating network is also used to heat domestic hot water, solar heating systems can reduce $\mathrm{LCOH}$. The lowest $\mathrm{LCoH}$ can be reduced to $0.29 \mathrm{CNY} / \mathrm{kWh}$ in the BAU scenario, about $8 \%$ compared to the system without domestic hot water load.

4) Land rent can significantly affect $\mathrm{LCOH}$ in all the investigated systems. As the land rent increases, the economic benefits that solar thermal brings to the system gradually decrease until a solar heating system becomes an economic disadvantage.

5) If the price of wood pellets is lower than $1100 \mathrm{CNY} /$ ton, LCoH increases with a higher SF for the combination of solar thermal with biomass boilers. Only when the price of the wood pellet is higher than $1100 \mathrm{CNY} /$ ton, can the solar thermal system reduce LCoH.

6) Time-of-use pricing system for electricity can reduce the lowest $\mathrm{LCOH}$ of the heat pump combinations by $8 \%$ to $10 \%$.

7) Considering the preferential use of solar energy, the order of selection of auxiliary heat sources with the most significant economic benefits depends on not only the local climate conditions but also electricity prices and gas prices. From an economic point of view, the selection of the auxiliary heat source will play a role.

\section{Acknowledgment}

This research was financially supported by the International Copper Alliance Asia and the International Metal Solar Industrial Alliance China, grant IDs: P018030059. The data presented in this study is used only for research purpose. 


\section{References}

[1] Building Energy Efficiency Research Center of Tsinghua University, Research Report on The Annual Development of Building Energy Efficiency in China 2015. Beijing: China Building Industry Press, 2015.

[2] J. Lin and B. Lin, "Heat tariff and subsidy in China based on heat cost analysis," Energy Econ., vol. 71, pp. 411-420, 2018.

[3] National Energy Administration of China, "Clean Heating Plan in North China in Winter ( 2017 - 2021 )," Beijing, China, 2017.

[4] H. Fang, J. Hao, and Y. Jiang, "Northern new heating model low grade industrial waste heat applied to urban central heating," Build. Sci., vol. 28, no. S2, pp. 11-14+17, 2012.

[5] M. A. Sayegh et al., "Trends of European research and development in district heating technologies," Renew. Sustain. Energy Rev., vol. 68, pp. 1183-1192, 2017.

[6] A. R. Mazhar, S. Liu, and A. Shukla, "A state of art review on the district heating systems," Renew. Sustain. Energy Rev., vol. 96, no. September 2017, pp. 420-439, 2018.

[7] J. Huang and Y. Xu, "The development status and trend of solar district heating in Europe," Constr. Sci. Technol., no. 4, pp. 63-69, 2017.

[8] A. Goumba, S. Chiche, X. Guo, M. Colombert, and P. Bonneau, "Recov'Heat: An estimation tool of urban waste heat recovery potential in sustainable cities," AIP Conference Proceedings 1814, 020038, 2017.

[9] U. Persson and S. Werner, "District heating in sequential energy supply," Appl. Energy, vol. 95, pp. 123131, 2012.

[10] Danish Energy Agency, "Regulation and planning of district heating in Denmark," 2016.

[11] Z. Tian et al., "Large-scale solar district heating plants in Danish smart thermal grid: Developments and recent trends," Energy Convers. Manag., vol. 189, no. October 2018, pp. 67-80, 2019.

[12] M. G. Fernández, C. Roger-Lacan, U. Gährs, and V. Aumaitre, Efficient district heating and cooling systems in the EU, no. December. JRC, 2016.

[13] H. Lund et al., "4th Generation District Heating (4GDH). Integrating smart thermal grids into future sustainable energy systems.," Energy, vol. 68, pp. 1-11, 2014.

[14] R. Zheng, B. Lu, Z. Li, and T. He, "Technical code for solar heating system(GB50495-2009)," China Building Industry Press, Beijing, 2009.

[15] Y. Liu, Y. Yu, and D. Kong, "Solar fraction of residential building in north-west China," J. Xi'an Univ. Archit. Technol. Sci. Ed., vol. 43, no. 2, pp. 272-276, 2011.

[16] S. Liu, B. Hao, X. Chen, C. Yao, and W. Zhou, "Analysis on limitation of using solar fraction ratio as solar hot water system design and evaluation index," Energy Procedia, vol. 70, pp. 353-360, 2015.

[17] Y. Louvet et al., "Guideline for levelized cost of heat (LCOH) calculations for solar thermal applications," 2017.

[18] B. C. Riggs et al., "Techno-economic analysis of hybrid PV/T systems for process heat using electricity to subsidize the cost of heat," Appl. Energy, vol. 208, no. May, pp. 1370-1378, 2017.

[19] Z. Tian, B. Perers, S. Furbo, and J. Fan, "Thermo-economic optimization of a hybrid solar district heating plant with flat plate collectors and parabolic trough collectors in series," Energy Convers. Manag., vol. 165, pp. 92-101, 2018.

[20] M. Vesterlund, A. Toffolo, and J. Dahl, "Optimization of multi-source complex district heating network, a case study," Energy, vol. 126, pp. 53-63, 2017.

[21] Q. Zhang, L. Zhang, J. Nie, and Y. Li, "Techno-economic analysis of air source heat pump applied for 
space heating in northern China," Appl. Energy, vol. 207, pp. 533-542, 2017.

[22] B. Qi, "Lowest work temperature of air source heat pump systems," Heat. Vent. Air Cond., vol. 37, no. 11, pp. 49-52, 2007.

[23] F. Guo, "Study on seasonal thermal energy storage of solar energy and industrial waste heat for urban district heating," Tsinghua University, 2018.

[24] Y. Liu, F. Zhao, and C. Zhang, "Analysis on operation characteristics of ground source heat pump system in cold area in winter," Cryog. Supercond., no. 12, pp. 80-83, 2017.

[25] Q. Guan, "Study on Solar-Ground Coupled Heat Pump with Seasonal Storage by TRNSYS," Tianjin Universicity, 2009.

[26] Z. Liu, J. Wang, W. Liu, and G. Peng, "Experimental study on heating operation of composite ground source heat pump system in winter," Renew. Energy Resour., vol. 25, no. 6, pp. 47-50, 2007.

[27] J. Jiang and Q. Sun, "Solar Energy and Gas Fired Boiler Combined in Large Scale Water Heating System," J. Shandong Inst. Commer. Technol., vol. 12, no. 6, pp. 83-87, 2012.

[28] G. Liu and Z. Yang, "Application of energy saving technology in solar energy and gas boiler combined heating control system in Olympic village," in 2012 Excellent Papers of Beijing Mechanical Engineering Society, 2012, pp. 110-114.

[29] H. Xie, C. Zhang, B. Hao, S. Liu, and K. Zou, "Review of solar obligations in China," Renewable and Sustainable Energy Reviews, vol. 16, no. 1. pp. 113-122, 2012.

[30] W. Li, "Computation and Research on Solar Heating System with Seasonal Water Tank Heat Storage," North China Electric Power University, 2012.

[31] M. Liu, X. Li, L. Duanmu, and L. Liu, "Review of Application and Optimization on Central Solar Heating Plants with Seasonal Water Storage," Build. Energy Environ., vol. 34, no. 11, pp. 26-30, 2015.

[32] G. Zhang, G. Yu, and J. He, "Study on parameters of Large-scale central solar heating system with seasonal storage for housing estate," Heat. Vent. Air Cond., no. 8, pp. 113-116, 2007.

[33] X. Wu and Y. Wu, "Research and practice of solar energy heat storage technology across seasons," Constr. Sci. Technol., no. 18, pp. 54-56, 2016.

[34] X. Li, "Numerical Research on a Domestic Solar Heating System with Underground Cylinder Thermal Storage," Chongqing University, 2017.

[35] R. Zheng and J. Nie, "Analysis for Marketization Development Prospect of Large-scale Solar Heating Combisystems in China," Energy Procedia, vol. 70, pp. 574-579, 2015.

[36] J. Huang, Z. Tian, and J. Fan, "A comprehensive analysis on development and transition of the solar thermal market in China with more than 70 \% market share worldwide," Energy, vol. 174, pp. 611-624, 2019.

[37] W. Xiong, Y. Wang, B. V. Mathiesen, H. Lund, and X. Zhang, "Heat roadmap china: New heat strategy to reduce energy consumption towards 2030," Energy, vol. 81, pp. 274-285, 2015.

[38] K. He and X. Li, "The research report on the comprehensive control of bulk coal in China (2018)," Beijing, 2018.

[39] J. Huang, J. Fan, and S. Furbo, "Feasibility study on solar district heating in China," Renew. Sustain. Energy Rev., vol. 108, no. July 2018, pp. 53-64, 2019.

[40] National Bureau of Statistics of China, "In 2016, the income of the national residents increased steadily, and the consumption of residents further improved," National Bureau of Statistics of China, 2016. [Online]. Available: http://www.stats.gov.cn/tjsj/sjjd/201701/t20170120_1456174.html. [Accessed: 27-Aug-2018].

[41] Y. Shen, "The Rise and Fall of Chinese Rural Governance and Its Reconstruction," Strateg. Manag., no. 
6, pp. 1-34, 1998.

[42] Y. Li, "Effect of Outflow of Rural Workforce on Change of Rural Population Structure," J. Henan Inst. Eng., vol. 29, no. 1, pp. 27-31, 2014.

[43] Z. Li, Y. Xu, and J. Huang, "Scale-up advantage of seasonal heat storage solar district heating," Dist. Heat., no. 5, pp. 29-35, 2017.

[44] P. A. Sørensen, J. E. Nielsen, R. Battisti, T. Schmidt, and D. Trier, "Solar district heating guidelines: Collection of fact sheets," 2017.

[45] International Organization for Standardization, "ISO 9806:2013 Solar energy - Solar thermal collectors Test methods," 2013.

[46] Z. Tian, B. Perers, S. Furbo, and J. Fan, "Analysis and validation of a quasi-dynamic model for a solar collector field with flat plate collectors and parabolic trough collectors in series for district heating," Energy, vol. 142, pp. 130-138, 2018.

[47] B. Perers, "Description of ScenoCalc ( Solar Collector Energy Output Calculator ), a program for calculation of annual solar collector energy output," Copenhagen, 2016.

[48] B. Perers, P. Kovacs, M. Olsson, M. Persson, and U. Pettersson, "A New Tool For Standardized Collector Performance Calculations," 2006.

[49] W. Kong, B. Perers, J. Fan, S. Furbo, and F. Bava, "A new Laplace transformation method for dynamic testing of solar collectors," Renew. Energy, vol. 75, pp. 448-458, 2015.

[50] Ministry of Housing and Urban-Rural Development of China, "Design Standard for Energy Efficiency of Residential Buildings in Severe Cold and Cold Zones(JGJ26-2010)," China Archit. Build. Press (in Chinese), no. JGJ26-2010, 2010.

[51] China Academy of Building Research, "Energy Conservation Design Standard for New Heating Residential Buildings (JGJ26-95)," Beijing, 1996.

[52] Q. Zhang and H. Yang, China Standard Weather Data for Analyzing Building Thermal Conditions. Beijing: China Building Industry Publishing House, 2012.

[53] U.S.National Aeronautics and Space Administration, "NASA Surface meteorology and Solar Energy," 2018. [Online]. Available: https://eosweb.larc.nasa.gov. [Accessed: 20-Dec-2018].

[54] Ministry of Housing and Urban-Rural Development of China, "Design Standard for Energy Efficiency of Residential Buildings in Hot Summer and Cold Winter Zone (JGJ134 - 2010)," Beijing, 2010.

[55] State Grid of China, "State grid online business hall," 2018. [Online]. Available: http://www.95598.cn/static/html//person/sas/es//PM06003001_786.shtml. [Accessed: 16-Sep-2018].

[56] Alibaba Group, "Alibaba purchases wholesale platform," 2018. [Online]. Available: https://www.1688.com/. [Accessed: 16-Sep-2018].

[57] X. Dong, Q. Tian, and Y. Shang, "Analysis on Low-temperature Heating Performance of Air Source Heat Pump Coupled with Scroll Compressor and Enhanced Vapor Injection," Fluid Mach., vol. 45, no. 03, pp. 81-86, 2017.

[58] X. Guo and A. P. Goumba, "Air source heat pump for domestic hot water supply: Performance comparison between individual and building scale installations," Energy, vol. 164, pp. 794-802, 2018.

[59] X. Guo and A. P. Goumba, "Process Intensification Principles Applied to Thermal Energy Storage Systems-A Brief Review," Front. Energy Res., vol. 6, no. March 2018, pp. 1-10, 2018.

[60] Ministry of Housing and Urban-Rural Development of China, Design code for heating ventilation and air conditioning of civil buildings (GB 50736-2012). Beijing: China Building Industry Press, 2012.

[61] Ministry of Housing and Urban-Rural Development of China, "Technical specification for floor radiant heating(JGJ142-2004)," 2004. 
[62] C. Gan and C. Yang, "Fan coil application in heating system," Technol. Wind, no. 10, p. 152, 2017.

[63] Z. Wang, W. Jiang, and J. Liu, "Experimental study on thermal performance of capillary network in winter heating," Build. Energy Effic., vol. 42, no. 11, pp. 16-19, 2014.

[64] J. Chen, Q. Liang, N. Li, Y. Gao, H. Liu, and W. Yang, "Experimental study on comparison of indoor environment with capillary network heating," J. Civil,Architectural Environ. Eng., vol. 40, no. 2, pp. 8894, 2018.

[65] F. Meng, "Study on performance parameters of capillary floor radiant heating," Chongqing University, 2017.

[66] M. He, D. Liu, and S. Li, "Economic Comparison of Different Heating Methods for Residential Buildings in Central Heated Area," Energy Conserv. Technol., vol. 26, no. 4, pp. 340-346, 2008.

[67] J. Xu, R. Z. Wang, and Y. Li, "A review of available technologies for seasonal thermal energy storage," Sol. Energy, vol. 103, pp. 610-638, 2014.

[68] The office of Beijing Municipal People's Government, “The heat price in Beijing in 2018-2019," 2018. [Online]. Available: http://www.beijing.gov.cn/bmfw/zt/2017djgn/. [Accessed: 20-Dec-2018].

[69] C. Peng and B. Hao, From Solar Energy to Solar Can, Efficiency and design of solar water heating system, 1st ed. Beijing: China Building Industry Press, 2018.

[70] "Technical Code for Solar Water Heating System of Civil buildings (GB 50364-2005)," China Building Industry Press, 2005. 